\title{
企業の研究者・技術者の情報アクセス行動の分析(1)
}

\author{
小野寺夏生*1, 水上政之 ${ }^{* 2}$ ，丸毛一彰*3, 西村邦雄*3
}

\section{Behavior analysis for information acquisition of scientists and engineers in industry (I)}

ONODERA Natsuo, MIZUKAMI Masayuki, MARUMO Kazuaki, NISHIMURA Kunio

[著者抄録] 約 60 の企業の研究者・技術者延べ 600 名に, 1 週間にわたって每日の科学技術 情報へのアクセス行動を記録してもらった。3,600のアクセス行動記録を, 入手しょうとした情 報の種類,アクセス手段。入手の契機と目的, 必要度と緊急度, 得られた結果に対する满足度 と入手時間等の観点から分析した。回答者の一部に対して補完的なアンケート調查およびヒア リング調查を実施し，情報収集に充てている時間と費用，種々の情報入手手段に対する評価， 商用データベースに対する評洒と今後の期待等を質した。科学技術情報に対する主要な入手手 段は，各種一次資料，人脈，個人の蓄積ファイルである。商用データベースも案外普及し，0.44 回/人・週の割合で使用されている。

[著者付与キーワード] 情報収集, 研究開発, 企業, 技術者, 研究者, 一次資料, データベ ース，情報サービス，社内情報，人脈

[Author Abstract] Information acquisition actions for a week were recorded by 660 scientists and engineers in about 60 industrial companies. Approximately 3600 records of the actions were analysed in terms of the kind of information to be acquired, the tools to be accessed for information acquisition, the cause for, and the purpase of, information acquisition, necessity and urgency of information to be acquired, the deqee of satisfaction for information abtained, and the pesiod needed for information acquisition. Additionally, a part of poinelists were rent a questionnaise and inteririewed to answer time and money spended for information acquisition and evalwation of various tools for information acquisition, particularly of commercial databases. The main accessing tools are various primary materials, personal connection and personal files. Commercial databases are used 0.44 times per week by a scientist/engineer.

[Keywords by Author] Information acquisition, Research and development, Industry, Scientists Engineers, Primary materials, Databases, Information services, In-house information, Personal connection

\footnotetext{
* 1 JICST 企画室

（广 100 千代田区永田町 2-5-2） Tel。03(581) 6411

* 2 JICST 経理部

(同上)

* 3 (社)科学技術と経済の会 研究部（广 102 千代田区飯田橋 2-4-5） Tel。03 (263) 5501

* 1 JICST, Planning Office * 2 JICST, Accounting and Finance Dpt.

( $5-2$, Nagatacho 2-chome, Chiyoda-ku, 100)

* 3 JAPAN TECHNO-ECONOMICS SOCIETY Research Dpt.

( $4-5$, Iidabashi 2-chome, Chiyoda-ku, 102)
} 


\section{1.はじめに}

研究者や技術者が日常の活動を行う際, 研究ア イディアの醸成, 研究テーマの設定, 研究の実施 と整理，産業・市場あるいは競争企業の動向把握 などのために，種々の情報の収集活動が必要にな る。科学技術情報に対する基本的な二ーズは，こ のような現場の研究者や技術者の日常の活動から 発生する。したがって, 情報サ一ビスに携わる我久 にとって，研究者・技術者の情報収集活動の実態 を知ることは最も重要な関心事であるといってよ いであろう。

従来，このような害態の把握はアンケート調査 やヒアリング調査によって行われてきた。比較的 最近では, 科学技術庁からの委託により, 未来工 学研究所が, 民間企業, 公的試験研究機関, 大学 の研究開発担当者を対象（回収 355 名）に，科学 技術情報利用の実態，データベースへの要望と課 題, 将来へのニーズ等について調査したものがあ る ${ }^{1)}$ 。この種の調查は大小様々な規模で多数行わ れているが，以下のような限界があることは否定 できない。

（1）個々の情報入手活動には立ち入れず，マク 口的な事実，意見，評価，要望を聞くことに なるので，梁い実態分析ができない。

(2) 回答される事実や意見に，主観的な印象や タテマエが含まれたり，設問の仕方に左右さ れることがある。

そこで本調查においては, より実証的に研究 者・技術者の情報入手活動を把え, 科学技術情報 への彼等のニーズがどのようなところに根ざして いるかを探るため, 日常の活動の中で行った個及 の情報アクセス行動を記録してもらい，それを分 析するという方法を採った。この方法は，ずっと 以前に Garvey らが研究者のコミュニケーション と成果発表の実態についての大規模な調査を行っ た際に採られたことがある2)。

本調査のもう一つの特徵は, 調査の対象を企業 に所属する研究者・技術者に限ったことである。 研究者全体の行動分析ということであれば, 当然
大学や国公立試験研究機関も含まなければならな いところであるが，対象を企業に絞ったのは以下 の理由による。

（1）大学・公共機関と企業とでは, 研究者の行 動パターンに大きな違いが予想されることか ら，もし全体を調查対象にしたとすれば，こ れらの所属機関性格別に分析する必要があ る。しかし，限定された調查規模の中で詨象 を異なるクラスに細分するよりも，あるクラ スに限定してそこに調查資源を集中する方 が，信頼性の高い結果を得る上で得策と考え た。

（2）企業は大学や公共機関に比べて情報収集活 動に対する目的意識が明確であり，かつその 活動も活発であるため，情報サービス機関か ら見た現在および将来の関心も高い。

本調査の方法と主要な結果については既に別の ところで報告した ${ }^{3)}$ が，主に単純集計の分析のみ であった。しかし，この調査で得られたいろいろ な項目への回答を組み合わせれば，さらに興味あ る情報アクセス行動が分析される。また, この実 態調査を補完する意味で, 調查協力者に対して実 施したアンケートやヒアリングの結果は概ね未報 告である。そこで本稿では, 参照文献 3)での報告 の内容も含めて, 調査の全容を詳細に述べた。

以下 2 で調査の内容と方法を述べた後， 3 と 4 では既に文献 3)で報告した単純集計の結果と，入 手しようとした情報の種類とそのアクセス手段の 間の関係についての結果を, 特徵の分析も加えて 示す。5ではより梁い項目間クロス集計の分析結 果について述べ， 6 と7で補完的に行ったアンケ 一ト調査とヒアリング調查の結果を述べる。そし て 8 で本調查全体に対する我々の評価および反 省，および情報サービス側から調査の結果をどう 見るかについて考察する。

なお，この号では 1 ～5まで，次号において 6 〜8を報告する。 


\section{2. 調査の内容と方法}

\section{1モニタ一調查}

モニタ一調查は本調査の中核をなすもので，従 来のアンケートやヒアリング中心の「意見の調査」 ではなく，「事実の調査」を意図したものである。 この意図を実現するため，以下のような調査を行 った。

\section{(1) 調査内容}

毎日の活動の中で行った個々の科学技術情報ア クセス行動（1日 5 件以内）について，予配付 した調査票に以下の事項を記録する。(7)以外は択 一回答，(7)のみは選択肢のうちから 3 個以内を回 答する。

(1)入手しようとした科学技術情報の種類

(2)当該情報を入手しようとした契機

(3)入手の目的（どのような業務への使用か）

(4)当該情報を必要とした程度

(5)入手の緊急性

(6)的確な情報が得られることに対する期待度

(7)入手のために用いたアクセス手段

(8)結果が得られるまでの時間

(9)結果に対する満足度

(10)最も満足を得たアクセス手段（7)の中から 1 個を選択）

8〜10については，アクセス行動の時点ですぐに 答が得られるとは限らないので, 調査終了後約 1
週間調査票を手元に留置き，結果について記入 後回収した。

(2) 調查対象

製造業, 建設業, 電気がス業の約 60 社の協力を 得て，これらの研究部門の他，企画・管理・技術 関係の部門に属する研究者・技術者を調査の対象 とした。

\section{(3) 調查の規模}

1 回の調查単位を 1 週間（月曜～日曜）とし， 1 人の技術者がこの期間にわたって毎日の情報ア クセス行動を記録する。約 200 人の技術者に対し, 適当な期間を置いて 3 回（3 週）にわたって調査 を行った。したがって延べ 600 人・週の調査結果 が得られたことになる。この状況を表 1 に示す。 また, 3 回目の回答者 162 名の属する企業の業種 と資本金規模による分布を表 2 に示す。

調査は同一の協力者に対して 3 回調査票を送る ことを原則としたが，個人の都合等により必ずし もその通りにならず, 中途で別の人に交代したり， 中断したため新たに他の人に依頼したりした。し たがって200名の 3 週にわたる記録というより, 延べ 600 名の 1 週間の記録という観点から整理し た。延べ 600 名の回答者の所属部門と職位の分布 を表了に示す。

\section{2 補完アンケート調査}

第 2 回のモニタ一調查対象者 203 名に対し, モ
表 1 モニター調査の回収状況

$\left.\begin{array}{|c|c|c|}\hline \text { 調查回次 } & \text { 回収回答 } & \text { 合計サンプル数 } \\ \hline 1 & 235 & \\ 2 & 203 & \\ 3 & 162 & 600\end{array}\right\}$

表 3 モニター調査回答者の所属部門・職位の分布

(表 1 に示した延べ 600 名に対する分布)

\begin{tabular}{|c|c|c|c|}
\hline 所属部門 & 管理職 & 部門員 & 計 \\
\hline 企画部門 & $59(9.8 \%)$ & $68(11.3 \%)$ & $127(21.2 \%)$ \\
管理部門 & $33(5.5 \%)$ & $14(2.3 \%)$ & $47(7.8 \%)$ \\
技術部門 & $50(8.3 \%)$ & $43(7.2 \%)$ & $93(15.5 \%)$ \\
研究部門 & $165(27.5 \%)$ & $163(27.2 \%)$ & $328(54.7 \%)$ \\
\hline N.A. & - & - & $5(0.8 \%)$ \\
\hline 計 & $307(51.2 \%)$ & $288(48.0 \%)$ & $600(100.0 \%)$ \\
\hline
\end{tabular}


ニタ一調査では直接把握が困難な以下のような事 項を知るため，モニタ一調查の終了後アンケート 調査を行った（回収 88 名）。

(1)科学技術情報の収集に費している時間

(2)自由裁量できる研究開発費用と，その中で情
報調查に充てている費用

(3)社外商用データベースの利用経験およびそれ

に対する要望事項

(4)専門的科学技術情報を入手するための諸手段

に対する評価

表 2 モニタ一調查協力者の属する企業の

業種別・規模別内訳

\begin{tabular}{|c|c|c|c|c|c|c|c|c|c|}
\hline \begin{tabular}{|l|} 
資本金 \\
業種 \\
\end{tabular} & $\begin{array}{c}10 \text { 億円 } \\
\text { 未満 }\end{array}$ & $\begin{array}{l}10 \text { 億円以上 } \\
50 \text { 億円未満 }\end{array}$ & $\begin{array}{l}50 \text { 億円以上 } \\
100 \text { 億凍满 }\end{array}$ & $\begin{array}{l}100 \text { 億円以上 } \\
500 \text { 億円未満円 }\end{array}$ & $\begin{array}{l}500 \text { 億円以上 } \\
1000 \text { 億円未満 }\end{array}$ & $\begin{array}{c}1000 \text { 億円 } \\
\text { 以上 }\end{array}$ & 不明 & 計 & $\begin{array}{l}\text { 日本の企業 } \\
\text { 全体の研究 } \\
\text { 者の比 }(\%)\end{array}$ \\
\hline 建設 & & $\begin{array}{c}5(3) \\
(45) \\
{[50]}\end{array}$ & & $\begin{array}{c}3(2) \\
(27) \\
{[5]}\end{array}$ & $\begin{array}{c}3(2) \\
(27) \\
\lceil 20\rceil\end{array}$ & & & $\begin{array}{r}11(7) \\
(100) \\
{[7]}\end{array}$ & 2.5 \\
\hline $\begin{array}{c}\text { 食品 } \\
\text { 繊維 } \\
\text { 紙・パルプ }\end{array}$ & & & & $\begin{array}{c}5(2) \\
(50) \\
\lceil 8\rceil\end{array}$ & & $\begin{array}{c}5(1) \\
(50) \\
{[9]}\end{array}$ & & $\begin{array}{c}10(3) \\
(100) \\
\lceil 6]\end{array}$ & 5.6 \\
\hline 化学 & $\begin{array}{c}3(2) \\
(16) \\
{[25]}\end{array}$ & & & $\begin{array}{c}16(7) \\
(84) \\
{[26]}\end{array}$ & & & & $\begin{array}{c}19(9) \\
(100) \\
\lceil 12]\end{array}$ & 21.7 \\
\hline 金属 & & & & $\begin{array}{c}5(3) \\
(63) \\
{[8]}\end{array}$ & $\begin{array}{c}2(1) \\
(25) \\
\lceil 13\rceil\end{array}$ & $\begin{array}{c}1(1) \\
(13) \\
\lceil 2]\end{array}$ & & $\begin{array}{l}8(5) \\
(100) \\
{[5]}\end{array}$ & 6.1 \\
\hline 機械 & $\begin{array}{c}9(1) \\
(18) \\
(75]\end{array}$ & $\begin{array}{c}1(1) \\
(2) \\
{[10]}\end{array}$ & $\begin{array}{c}2(1) \\
(4) \\
\lceil 25]\end{array}$ & $\begin{array}{c}11(2) \\
(22) \\
\lceil 18]\end{array}$ & $\begin{array}{l}8(1) \\
(16) \\
{[53]}\end{array}$ & $\begin{array}{c}18(2) \\
(37) \\
\lceil 33\rceil\end{array}$ & & $\begin{array}{c}49(8) \\
(100) \\
\lceil 30]\end{array}$ & 22.2 \\
\hline 電機 & & $\begin{array}{c}4(2) \\
(7) \\
{[40]}\end{array}$ & $\begin{array}{c}6(4) \\
(11) \\
{[75]}\end{array}$ & $\begin{array}{c}21(6) \\
(38) \\
\lceil 34]\end{array}$ & & $\begin{array}{c}22(7) \\
(40) \\
\lceil 41]\end{array}$ & $\begin{array}{c}2(1) \\
(4) \\
\lceil 100]\end{array}$ & $\begin{array}{c}55(20) \\
(100) \\
\lceil 34]\end{array}$ & 36.1 \\
\hline $\begin{array}{l}\text { 電力 } \\
\text { ガス }\end{array}$ & & & & & $\begin{array}{c}2(1) \\
(20) \\
\lceil 13\rceil\end{array}$ & $\begin{array}{c}8(5) \\
(80) \\
\lceil 15]\end{array}$ & & $\begin{array}{c}10(6) \\
(100) \\
{[6]}\end{array}$ & 1.9 \\
\hline 計 & $\begin{array}{c}12(3) \\
(7) \\
\lceil 100]\end{array}$ & $\begin{array}{c}10(6) \\
(6) \\
{[100]}\end{array}$ & $\begin{array}{c}8(5) \\
(5) \\
\lceil 100]\end{array}$ & $\begin{array}{c}61(22) \\
(38) \\
\lceil 100]\end{array}$ & $\begin{array}{c}15(5) \\
(9) \\
\lceil 100]\end{array}$ & $\begin{array}{c}54(16) \\
(33) \\
\lceil 100\rceil\end{array}$ & $\begin{array}{c}2(1) \\
(1) \\
{[100]}\end{array}$ & $\begin{array}{c}162(58) \\
(100) \\
{[100]}\end{array}$ & 96.1 \\
\hline
\end{tabular}

表中の数字は，上段：協力者人数 (企業数)

中段：同一業種内 (横方向)の百分率

下段：同一資本金規模内 (縦方向)の百分率

(この人数は，3 回目のモニタ一調査に回答した人である） 


\section{3 補完ヒアリング調査}

アンケート回答者からさらに 20 名を選び, 訪問 によってさらに詳しい意見を聞いた。ヒアリング のテーマは以下のように設定した。

（1）科学技術情報サービスの実状と満足度

(1)所属企業の企業内情報サービス体制の現状と 問題点

(2)情報収集に充てる時間，よく用いる情報入手 手段とその評価

(3)データベースの利用経験と評価（満足や不満 が得られた具体的経験を含む)

（2）科学技術情報サービスへの期待

(1)どのようなサービスを期待するか

(2)オンラインデータベース, SDI, CD-ROM 等 の各種サービスの認知度と満足度

（3）科学技術情報活動の重みが，個人の業務ある いは会社全体の中で変化しているかどうか

\section{3. モニター調査の結果——その1。単純集計}

\section{1 情報アクセスの回数}

2.1 で述べたような，延べ 600 人・週に対する 調査の結果, 約 3,600 回の情報アクセス行動が記 録された。すなわち, 平均 6 回 /人・週のアクセ ス行動があったことになる。

\section{2 情報アクセスの契機と目的}

どのようなきっかけで情報を入手しようとした かを表 4 に，その時の入手の目的（業務）を表 5 に示す。また，その情報をどの程度必要としたか を答えてもらった結果が表 6 である。大手の契機 および目的については, 当然のことながら, 企画。 管理部門と技術・研究部門はかなり異なる結果に なっている。

\section{表 4 情報を入手しょうとした契機}

\begin{tabular}{|c|c|c|c|c|c|}
\hline & \multirow{2}{*}{ 全体 } & \multicolumn{2}{|c|}{ 企画・管理部門 } & \multicolumn{2}{|c|}{ 技術・研究部門 } \\
\hline & & 管理職 & 部門員 & 管理職 & 部門員 \\
\hline \multirow{2}{*}{$\begin{array}{c}\text { a. 業務に関係なく, 自分の関心に基づ } \\
\text { く一般的な自己研修用資料として }\end{array}$} & 454 & 70 & 44 & 179 & 160 \\
\hline & 12.7 & 12.1 & 9.7 & 13.9 & 13.0 \\
\hline \multirow{2}{*}{$\begin{array}{l}\text { b. 自分の業務の企画段階で必要とされ } \\
\text { たため }\end{array}$} & 1,067 & 203 & 200 & 368 & 291 \\
\hline & 29.9 & 35.1 & 44.0 & 28.6 & 23.6 \\
\hline \multirow{2}{*}{$\begin{array}{l}\text { c. 自分の業務の実施段階で必要とされ } \\
\text { たため }\end{array}$} & 1,036 & 136 & 76 & 319 & 499 \\
\hline & 29.0 & 23.5 & 16.7 & 24.8 & 40.5 \\
\hline \multirow{2}{*}{$\begin{array}{l}\text { d. 自分の業務を整理するために必要と } \\
\text { されたため }\end{array}$} & 299 & 50 & 32 & 113 & 101 \\
\hline & 8.4 & 9.0 & 7.0 & 8.8 & 8.2 \\
\hline \multirow{2}{*}{ e. 同じ部門の上司・同僚等からの要望 } & 281 & 42 & 55 & 88 & 93 \\
\hline & 7.9 & 7.3 & 12.1 & 6.8 & 7.6 \\
\hline \multirow{2}{*}{ f。＼cjkstart社内他部門からの要請で } & 272 & 50 & 40 & 136 & 42 \\
\hline & 7.6 & 8.7 & 8.8 & 10.6 & 3.4 \\
\hline \multirow{2}{*}{ g. 社外からの要請で } & 114 & 18 & 7 & 65 & 23 \\
\hline & 3.2 & 3.1 & 1.5 & 5.0 & 1.9 \\
\hline \multirow{2}{*}{ h. その他 } & 51 & 7 & 1 & 21 & 22 \\
\hline & 1.4 & 1.2 & 0.2 & 1.6 & 1.8 \\
\hline \multirow{2}{*}{ 計 } & 3,574 & 578 & 455 & 1,289 & 1,231 \\
\hline & 100 & 100 & 100 & 100 & 100 \\
\hline
\end{tabular}

各欄の上段はアクセス行動の回数, 下段は総アクセス回数に対する百分率を示す（以下, 表 5～表 7, 表 9, 表 11 表 14 も同様) 


\section{3 入手しょうとした情報の種類}

どのような種類の情報を得ようとしたかについ ては，16 種類の情報から選択回答してもらった。 その結果は表 7 に示す通りであり，

(1)特定の科学技術分野の専門的情報

(2)科学技術の基礎的・一般的情報

(3)特定の製品・サービスの特徵・仕様・使用方

法・生産・消費に関わる情報

(4)特定の分野の科学技術関連データ

(5)特定の装置・設備・機器等に関する情報
の上位 5 種で全回答の 6 割強を占める。

しかし，企画・管理部門だけで見ると，「ある科 学技術的なアイディア・新企画を裏付け, 補強す るための情報」が上記(1)，(2)に次いで 3 位に喰い 込み，上記(3)，(4)，(5)が 1 位ずつ下がる。一方技 術・研究部門では上記の (1) (4)の順位はそのまま で，5位が「特定の分野の特許情報」になってい る。

表 3 と表 7 を組み合わせることにより, 部門別, 職位別の各技術者が，それぞれの情報に平均週何

表 5 情報入手の目的(業務)

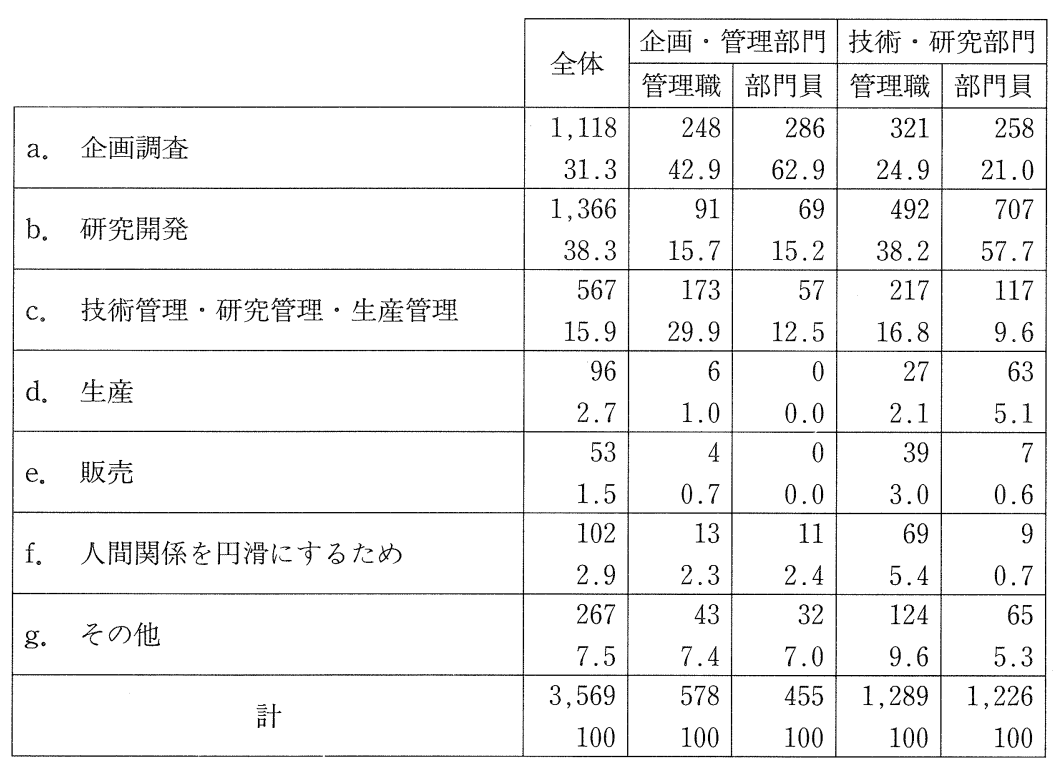

表 6 情報入手の必要度

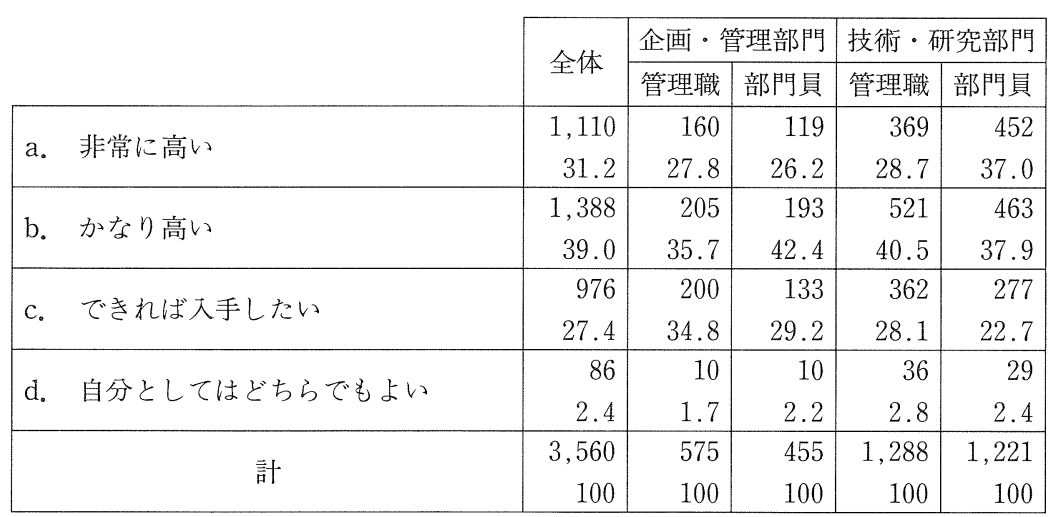


回アクセスしたかを求めることができる。主な情 報の種類についてこの結果を表 8 に示した。

\section{4 情報へのアクセスの手段}

これらの情報をどんな手段で入手しようとした かについては, 表 9 に示す 22 の手段から選択して もらった。この問についてのみ複数（三つ以内）
の回答を許した。表 9 （A 欄）に示すように，全 部で約 6,300の手段が採られており，全アクセス 回数が 3,600 回であることから 1 回のアクセス行 動当たり約 1.75 通りの手段が使われたことが示 される。

また，複数用いたアクセス手段のうち最も満足 を得な手段一つを答えてもらった結果を，同じく

表 7 入手しょうとした情報の種類

\begin{tabular}{|c|c|c|c|c|c|}
\hline & \multirow{2}{*}{ 全体 } & \multicolumn{2}{|c|}{ 企画・管理部門 } & \multicolumn{2}{|c|}{ 技術・研究部門 } \\
\hline & & 管理職 & 部門員 & 管理職 & 部門員 \\
\hline \multirow{2}{*}{ a. 科学技術の基礎的・一般的知識情報 } & 481 & 96 & 69 & 142 & 172 \\
\hline & 13.4 & 16.6 & 15.1 & 10.9 & 13.9 \\
\hline \multirow{2}{*}{ b. 特定の科学技術分野の専門的情報 } & 779 & 103 & 109 & 299 & 263 \\
\hline & 21.7 & 17.8 & 23.9 & 23.0 & 21.3 \\
\hline \multirow{2}{*}{ c. 特定の分野の科学技術関連デー夕 } & 296 & 51 & 33 & 113 & 99 \\
\hline & 8.2 & 8.8 & 7.2 & 8.7 & 8.0 \\
\hline \multirow{2}{*}{ d. 特定の分野の特許情報 } & 246 & 23 & 25 & 96 & 98 \\
\hline & 6.9 & 4.0 & 5.5 & 7.4 & 7.9 \\
\hline \multirow[t]{2}{*}{ e. 科学 } & 156 & 25 & 24 & 67 & 40 \\
\hline & 4.3 & 4.3 & 5.3 & 5.2 & 3.2 \\
\hline \multirow[t]{2}{*}{ f。実 } & 201 & 20 & 16 & 56 & 108 \\
\hline & 5.6 & 3.5 & 3.5 & 4.3 & 8.8 \\
\hline \multirow[t]{2}{*}{ g。 特 } & 169 & 33 & 27 & 62 & 47 \\
\hline & 4.7 & 5.7 & 5.9 & 4.8 & 3.8 \\
\hline h。 ある科学技術的なアイディア・新企 & 210 & 60 & 35 & 53 & 61 \\
\hline 画を裏付け・補強するための情報 & 5.9 & 10.4 & 7.7 & 4.1 & 4.9 \\
\hline i。 特定の科学技術分野の装置・設備・ & 248 & 40 & 23 & 94 & 89 \\
\hline 機器等に関する情報 & 7.0 & 6.9 & 5.0 & 7.2 & 7.2 \\
\hline j。 特定の製品・サービスについての歷 & 87 & 9 & 21 & 34 & 23 \\
\hline 史・現状・展望に関わる情報 & 2.4 & 1.6 & 4.6 & 2.6 & 1.9 \\
\hline k 。 特定の製品・サービスの特徵・仕様・ & 403 & 56 & 36 & 142 & 166 \\
\hline 使用方法・生産・消費に関わる情報 & 11.2 & 9.7 & 7.9 & 10.9 & 13.5 \\
\hline 1. 特定の企業・機関の科学技術関連の & 78 & 24 & 23 & 24 & 7 \\
\hline 歴史・現状・展望に関する情報 & 2.2 & 4.2 & 5.0 & 1.9 & 0.6 \\
\hline m。特定の個人の科学技術的経歴やポテ & 66 & 11 & 7 & 32 & 15 \\
\hline ンシャルに関する情報 & 1.8 & 1.9 & 1.5 & 2.5 & 1.2 \\
\hline n。 特定の科学技術的属性・特徵を有す & 66 & 11 & 7 & 36 & 12 \\
\hline 企業・機関や個人の探索情報 & 1.8 & 1.9 & 1.5 & 2.8 & 1.0 \\
\hline o. 事故・災害・疾病等に関する科学技 & 31 & 3 & 0 & 24 & 4 \\
\hline 術的対策に関する情報 & 0.9 & 0.5 & 0.0 & 1.9 & 0.3 \\
\hline \multirow{2}{*}{ p. その他 } & 74 & 14 & 2 & 26 & 30 \\
\hline & 2.1 & 2.4 & 0.4 & 2.0 & 2.4 \\
\hline \multirow[b]{2}{*}{ 計 } & 3,591 & 579 & 457 & 1,300 & 1,234 \\
\hline & 100 & 100 & 100 & 100 & 100 \\
\hline
\end{tabular}


表9のB欄に示し，それぞれの手段の満足率 (利 用度数に対する満足を与えた度数の比)を求めた。

また，技術者の部門別，職位別に，技術者 1 人 当たり， 1 週当たりの主な手段へのアクセス回数 を求めたのが表 10 である。

科学技術情報の入手の手段としては,

(1)専門誌，新聞・図書等の一次資料

(2)人づてに得る情報

(3)個人の蓄積情報 が主流であって，二次資料，社外データベース， 社内情報部門等のいわゆる情報サービスの利用は 副次的である。しかしこれらの手段もあながち低 い利用とはいえず，平均的な技術者は，週当たり 社外二次資料を 0.3 回，社外データベースを 0.44 回利用子る他, 社内の担当部門に 0.65 回情報収集 を依頼している。

また，表 9 の満足率の欄を見ると，これらの情 報サービスによる情報入手は，個人蓄積資料や一 次資料に比べて利用度は低いものの，概して「当 たる」確率は高いことが判る。

\section{5 情報入手の緊急性と入手時間}

情報をどれくらいの期間内に入手したいと思っ たかが表 11 に, 実際に入手するのにどれくらいか かったかが表 12 に示されている。希望の半数が即 座ないし当日中であり，実際にも半分以上がその 日のうちに入手している。入手に 1 週間以上かけ てよいと思う要求は全体の約 6 回に 1 回で，1 1 人 当たりにすると 1 週間に 1 回程度である。

部門員の方が管理職より急いで情報を入手した いと思う傾向が強いが，結果はあまり差がない。

\section{6 入手情報に対する期待度と満足度}

自分の要求に対して適切な情報が得られること にあらかじめどれくらいの期待をもったかを表 13 に，実際に入手した情報への満足度はどうだっ たかを表 14 に示す。ここでの期待度は, 求める情 報の入手難易性や，アクセ久手段の適切性の予想 を反映していると思われる。期待度に比べて満足 度は若干下回る結果になっている。

衰 8 主な情報の種類に対する 1 人・週当たクのアクセス回数

\begin{tabular}{|c|c|c|c|c|c|}
\hline \multirow[b]{2}{*}{ 情報の種類 (上位 7 種) } & \multirow{2}{*}{ 全体 } & \multicolumn{2}{|c|}{ 企画・管理部門 } & \multicolumn{2}{|c|}{ 技術・研究部門 } \\
\hline & & 管理職 & 部門員 & 管理職 & 部門員 \\
\hline a. 基礎的 - 一般的情報 & 0.81 & 1.04 & 0.84 & 0.66 & 0.83 \\
\hline b. 特定の専門的情報 & 1.31 & 1.12 & 1.33 & 1.39 & 2.28 \\
\hline c. 特定の分野のデータ & 0.50 & 0.55 & 0.40 & 0.53 & 0.48 \\
\hline d. 特定の分野の特許 & 0.41 & 0.25 & 0.30 & 0.45 & 0.48 \\
\hline h。アイディア・新企画を補強する情報 & 0.35 & 0.65 & 0.43 & 0.25 & 0.30 \\
\hline i。装置・設備・機器の情報 & 0.42 & 0.43 & 0.28 & 0.44 & 0.43 \\
\hline k。製品・サービスの特徵・仕様等の情報 & 0.68 & 0.61 & 0.44 & 0.66 & 0.81 \\
\hline 全 体 & 6.04 & 6.29 & 5.57 & 6.05 & 5.99 \\
\hline
\end{tabular}


表 9 情報入手手段に対するアクセス回数および その中で満足を得たアクセス回数

\begin{tabular}{|c|c|c|c|c|c|c|c|}
\hline & \multirow[b]{2}{*}{ (A) } & & & & & \multirow{2}{*}{$\begin{array}{l}\text { 全体 } \\
\text { (B) }\end{array}$} & \\
\hline & & 管理職 & 部門員 & 管理職 & 部門員 & & \\
\hline a. 個人的な蓄積情報 (自分のファイル) & 762 & 103 & 76 & 272 & 310 & 291 & \multirow{2}{*}{38.2} \\
\hline を活用した & 12.1 & 9.9 & +9.3 & 12.1 & 14.2 & 8.8 & \\
\hline b。自分自身で社内の蓄積情報を，探し & 78 & 3 & 4 & 11 & 60 & 73 & \multirow{2}{*}{93.6} \\
\hline 活用した & 1.2 & 0.3 & 0.5 & 0.5 & 2.8 & 2.2 & \\
\hline b-1。社内作成のドキュメンテーシ & 435 & 53 & 55 & 197 & 130 & 198 & \multirow{2}{*}{45.5} \\
\hline ヨン資料 & 6.9 & 5.1 & 6.7 & 8.7 & 6.0 & 6.0 & \\
\hline \multirow{2}{*}{$b-2$. 新聞 - 一般図書 } & 664 & 173 & 97 & 180 & 211 & 347 & \multirow{2}{*}{52.3} \\
\hline & 10.5 & 16.6 & 11.8 & 8.0 & 9.7 & 10.5 & \\
\hline \multirow{2}{*}{$\mathrm{b}-3$ 。専門誌 } & 823 & 174 & 112 & 260 & 276 & 387 & \multirow{2}{*}{47.0} \\
\hline & 13.0 & 16.7 & 13.7 & 11.5 & 12.7 & 11.7 & \\
\hline \multirow{2}{*}{ b-4. 特許公報 } & 165 & 10 & 8 & 72 & 71 & 73 & \multirow{2}{*}{44.2} \\
\hline & 2.6 & 1.0 & 1.0 & 3.2 & 3.3 & 2.2 & \\
\hline \multirow{2}{*}{$b-5$ 。辞典・ハンドブック・デー夕集 } & 293 & 45 & 51 & 53 & 144 & 115 & \multirow{2}{*}{39.2} \\
\hline & 4.6 & 4.3 & 6.2 & 2.4 & 6.6 & 3.5 & \\
\hline \multirow{2}{*}{$b-6$ 。法令集・規則集・規格集 } & 78 & 14 & 6 & 24 & 34 & 34 & \multirow{2}{*}{43.6} \\
\hline & 1.2 & 1.4 & 0.7 & 1.1 & 1.6 & 1.0 & \\
\hline b-7。:カタログ・パンフレット・商品 & 324 & 38 & 34 & 94 & 157 & 124 & \\
\hline 仕様書等 & 5.1 & 3.7 & 4.2 & 4.2 & 7.2 & 3.8 & 38. \\
\hline & 195 & 34 & 33 & 61 & 67 & 76 & \\
\hline 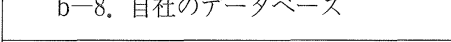 & 3.1 & 3.3 & 4.0 & 2.7 & 3.1 & 2.3 & 39. \\
\hline b一9. 社内セミナー・講演会等の利 & 76 & 4 & 21 & 35 & 16 & 51 & \\
\hline 用 & 1.2 & 0.4 & 2.6 & 1.6 & 0.7 & 1.6 & 67. \\
\hline & 71 & 9 & 5 & 37 & 19 & 22 & \\
\hline b-10。 その他 & 1.1 & 0.9 & 0.6 & 1.6 & 0.9 & 0.7 & 31.0 \\
\hline C. 自分自身で社外の蓄積情報を探し， & 27 & 0 & 2 & 13 & 12 & 28 & \\
\hline 活用した & 0.4 & 0.0 & 0.2 & 0.6 & 0.6 & 0.9 & 103. \\
\hline 利田 & 186 & 30 & 15 & 99 & 40 & 76 & \\
\hline 外一次 & 2.9 & 2.9 & 1.8 & 4.4 & 1.8 & 2.3 & 10 . \\
\hline c-2. 社外データベース・サービス & 259 & 34 & 39 & 119 & 64 & 164 & \\
\hline の利用 & 4.1 & 3.3 & 4.8 & 5.3 & 2.9 & 5.0 & 63.3 \\
\hline $\mathrm{c}$-3. 社外セミナー・講演会等の利 & 159 & 42 & 22 & 69 & 25 & 99 & \\
\hline 用 & 2.5 & 4.0 & 2.7 & 3.1 & 1.2 & 3.0 & 2. \\
\hline & 59 & 9 & 3 & 32 & 14 & 33 & \\
\hline$c-4$ & 0.9 & 0.9 & 0.4 & 1.4 & 0.6 & 1.0 & 55 \\
\hline d。 自分自身の社内の人脈(コネ)を利用 & 697 & 103 & 116 & 223 & 252 & 406 & \\
\hline し，生情報を収集・活用した & 11.0 & 9.9 & 14.2 & 9.9 & 11.6 & 12.3 & 58. \\
\hline e。 自分自身の社外の人脈 (コネ)を利用 & 340 & 32 & 35 & 143 & 128 & 254 & \\
\hline し，生情報を収集・活用した & 5.4 & 3.1 & 4.3 & 6.4 & 5.9 & 7.7 & 74.7 \\
\hline f。 社内の担当部門に情報収集を依頼し & 386 & 94 & 50 & 155 & 85 & 244 & \\
\hline た & 6.1 & 9.0 & 6.1 & 6.9 & 3.9 & 7.4 & .2 \\
\hline g。 社外のしるべき組織に情報収集を依 & 127 & 19 & 32 & 50 & 26 & 78 & \\
\hline 頼した & 2.0 & 1.8 & 3.9 & 2.2 & 1.2 & 2.4 & 01.4 \\
\hline h $z$ & 105 & 16 & 4 & 48 & 37 & 64 & 61 \\
\hline h. & 1.7 & 1.5 & 0.5 & 2.1 & 1.7 & 1.9 & 61.0 \\
\hline & 6,309 & \begin{tabular}{|l|}
1,039 \\
\end{tabular} & 820 & 2,247 & 2,178 & 3,237 & \\
\hline 言 & 100 & & 100 & & & 98.1 & 51.3 \\
\hline i. 満足できたアクセス手段はなかった & & & - & & & $\begin{array}{r}62 \\
1.9\end{array}$ & - \\
\hline 総 計 & & & 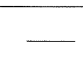 & & & $\begin{array}{r}3,299 \\
100\end{array}$ & \\
\hline
\end{tabular}


表 10 主なアクセス手段に対する 1 人・週当たクのアクセス回数

\begin{tabular}{|c|c|c|c|c|c|}
\hline \multirow[b]{2}{*}{ 情報アクセスの手段 } & \multirow{2}{*}{ 全体 } & \multicolumn{2}{|c|}{ 企画・管理部門 } & \multicolumn{2}{|c|}{ 技術・研究部門 } \\
\hline & & 管理職 & 部門員 & 管理職 & 部門員 \\
\hline a. 個人の蓄積情報 & 1.28 & 1.12 & 0.93 & 1.27 & 1.50 \\
\hline $\mathrm{b}-1$. 社内作成資料 & 0.73 & 0.58 & 0.67 & 0.92 & 0.63 \\
\hline b一 2。新聞・一般図書 & 1.12 & 1.88 & 1.18 & 0.84 & 1.02 \\
\hline$b-3$ 。専門誌 & 1.38 & 1.89 & 1.37 & 1.21 & 1.34 \\
\hline b-5.辞典・ハンドブック・デー夕集 & 0.49 & 0.49 & 0.62 & 0.25 & 0.70 \\
\hline b-7. カタログ・パンフレット & 0.54 & 0.41 & 0.41 & 0.44 & 0.76 \\
\hline $\mathrm{b}-8$ 。社内データベース & 0.33 & 0.37 & 0.40 & 0.28 & 0.33 \\
\hline$c-1$. 社外二次資料 & 0.31 & 0.33 & 0.18 & 0.46 & 0.19 \\
\hline$c-2$ 。社外データベース & 0.44 & 0.37 & 0.48 & 0.55 & 0.31 \\
\hline d. 社内の人脈 & 1.17 & 1.12 & 1.41 & 1.04 & 1.22 \\
\hline e. 社外の人脈 & 0.57 & 0.35 & 0.43 & 0.67 & 0.62 \\
\hline f. 社内の担当部門 & 0.65 & 1.02 & 0.61 & 0.72 & 0.41 \\
\hline 全 & 10.60 & 11.29 & 10.00 & 10.45 & 10.57 \\
\hline
\end{tabular}

表 11 情報入手に対する緊急性

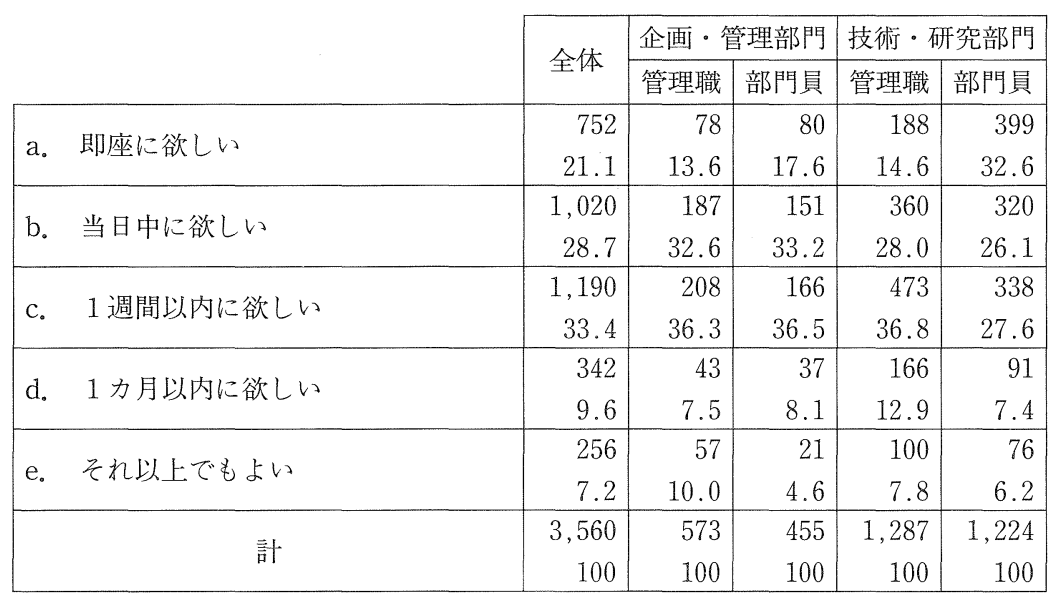




\section{4. モニター調査の結果一一の2。情報の} 種類とアクセス手段の間の関係

入手しようとした情報の種類と，入手に用いた アクセス手段の間の詳細なクロス集計の結果を表 15 に示した。ただし, 表 7 (情報の種類) および 表 9 (アクセス手段) に示す項目をそのまま用い ずに，類似の項目を合併したり，回答の少ない項
目を割愛している。項目を合併した場合，それに 対するコードは合併名のコードを単に接合させ （例えば情報の種類の j と k を合併して一つの項 目〈製品・サービスに関する情報〉とした時，こ れに対するコードは‘ $\mathrm{jk}$ ‘゙ある), 対比をしやすく した。

表 15 では個別の特徵をつかみ難いので, 以下に これを分析したいくつかの結果を示す。

表 12 情報入手に要した時間

\begin{tabular}{|c|c|c|c|c|c|c|}
\hline & \multirow{2}{*}{ 全体 } & \multicolumn{2}{|c|}{ 企画・管理部門 } & \multicolumn{2}{|c|}{ 技術・研究部門 } \\
\hline & & & 管理職 & 部門員 & 管理職 & 部門員 \\
\hline \multirow{2}{*}{\multicolumn{2}{|c|}{ a. その日の内 }} & 2,021 & 354 & 249 & 679 & 728 \\
\hline & & 57.3 & 62.2 & 56.0 & 53.1 & 60.0 \\
\hline \multirow{2}{*}{\multicolumn{2}{|c|}{ b. 数日以内 }} & 749 & 99 & 117 & 293 & 238 \\
\hline & & 21.2 & 17.4 & 26.3 & 23.0 & 19.6 \\
\hline \multirow{2}{*}{\multicolumn{2}{|c|}{ c. 1 週間以内 }} & 356 & 55 & 29 & 152 & 119 \\
\hline & & 10.1 & 9.7 & 6.5 & 11.9 & 9.8 \\
\hline \multirow{2}{*}{\multicolumn{2}{|c|}{ d。 1 週間以上 }} & 145 & 17 & 27 & 64 & 34 \\
\hline & & 4.1 & 3.0 & 6.1 & 5.0 & 2.8 \\
\hline \multirow{2}{*}{\multicolumn{2}{|c|}{ e. まだ結果が得られていない }} & 256 & 44 & 23 & 92 & 95 \\
\hline & & 7.3 & 7.7 & 5.2 & 7.2 & 7.8 \\
\hline \multirow{2}{*}{\multicolumn{2}{|c|}{ 計 }} & 3,527 & 569 & 445 & 1,280 & 1,214 \\
\hline & & 100 & 100 & 100 & 100 & 100 \\
\hline
\end{tabular}

(調査対象の週の終了後 1 週間調査票を手許に留置いた後回答。したがって上記の $)$ e.は，その時点でまだ結果が得られていない情報アクセス活動の度数である

表 13 適当な情報が入手できることに対する当初の期待度

\begin{tabular}{|c|c|c|c|c|c|}
\hline & 1 休 & 企画 - & 理部門 & 技術・不 & F究部門 \\
\hline & 全体 & 管理職 & 部門員 & 管理職 & 部門員 \\
\hline 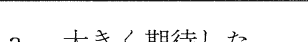 & 8.83 & 127 & 92 & 285 & 373 \\
\hline a.人己く期付した & 24.8 & 22.1 & 20.2 & 22.1 & 30.1 \\
\hline b hten期 & 1,547 & 254 & 198 & 604 & 482 \\
\hline D. 加 & 43.4 & 44.3 & 43.5 & 47.0 & 39.4 \\
\hline c 多小詛待1 to & 925 & 181 & 137 & 312 & 290 \\
\hline C. 多多期付しに & 26.0 & 31.5 & 30.1 & 24.2 & 23.7 \\
\hline 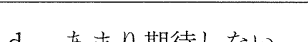 & 198 & 11 & 28 & 86 & 72 \\
\hline り期付しない & 5.6 & 1.9 & 6.2 & 6.7 & 5.9 \\
\hline $1 \mp$ & 8 & 1 & 0 & 1 & 6 \\
\hline e. 1 $2 ん C$ 期付 & 0.2 & 0.2 & 0.0 & 0.0 & 0.5 \\
\hline 計 & 3,561 & 574 & 455 & 1,288 & 1,223 \\
\hline 口| & 100 & 100 & 100 & 100 & 100 \\
\hline
\end{tabular}




\section{1 情報の種類ごとによく利用されるアクセ ス手段}

表 15 を行方向に見て行くと, 各情報の種類ごと によく利用されるアクセス手段がわかる。それぞ れの情報の種類ごとに，回数の多い順に累積が 50 \%を超えるまでアクセス手段を示すと表 16 のよ うになる。

特徵的なのは, 装置・設備・機器の情報, 製品・ サービスの情報，機関・人の情報については，社 内・社外の人脈を通しての情報入手に頼る割合が 高いことである。このことは，これらの情報につ いて専門誌や特許公報のようなメジャーな一次情 報源が少ないことによるのであろう。

社外データベースや社内情報担当部門のような 情報サービスの利用は, 特許情報以外では主要な アクセス手段になっていない。

\section{2 各アクセス手段によりょく入手される情 報}

表 15 を縦方向に見れば,それぞれのアクセス手 段がどのような情報の入手によく利用されるかを 知ることができる。表 16 で行ったのと同じよう
に，アクセス手段ごとに，回数の多い順にアクセ スされた情報の種類を, 累積が 50 \%を超えるまで 挙げてみると表 17 のようになる。

社外データベースの利用が特許情報と専門情報 へのアクセスのためが主流であるのに対し, 社内 データベースはデータへのアクセスの比重が高 い。これは, 社内で重要なデー夕がファクトデー タベースにされていることを暗示している。

また，社内・社外の人脈抒よび社内担当部門の 利用は, 製品・サービスや装置・機器の情報を知 るために最もよく使われており，このような情報 への潜在需要が大きいことを物語っている。

\section{3情報の種類ごとの各アクセス手段の满足率}

表 9 には，各アクセス手段の利用度数に対する 満足を得た度数の割合 (満足率) を示しているが, これを情報の種類ごとに分けて示したのが表 18 である。それぞれの闌に，アクセスの度数(分母)， そのうち満足を得た度数 (分子)，そして満足率 (\%) が記入されている。

この表から以下のことが言える。

（1）どの「情報の種類」に対しても，全体の満足

\section{表 14 得られた情報に対する満足度}

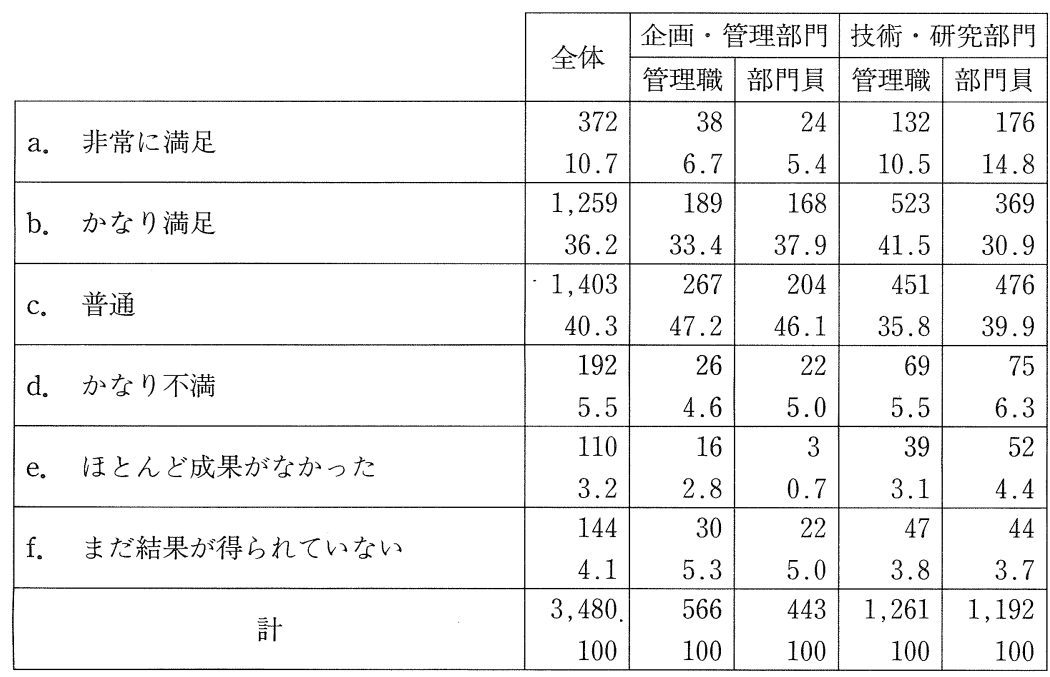

(表 12 と同様，調查対象の週の終了後 1 週間調査票を手許に留置いた後回答） 


\begin{tabular}{|c|c|c|c|c|c|c|c|c|c|c|c|c|c|}
\hline 满 & 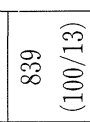 & 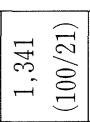 & 남 $\frac{\sigma}{8}$ & 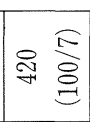 & 总 & 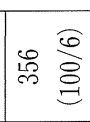 & $\stackrel{0}{\infty} \frac{10}{0}$ & 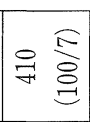 & 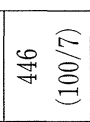 & 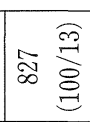 & 总 $\frac{0}{0}$ & 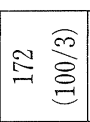 & $\begin{array}{ll}2 & 8 \\
0 & \varrho \\
0 & 8 \\
0 & 0\end{array}$ \\
\hline 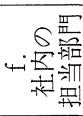 & 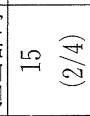 & $8 \stackrel{0}{\stackrel{\theta}{\oplus}}$ & $\infty \frac{\sigma}{E}$ & $\begin{array}{ll}\mathscr{\sigma} & \widehat{\sigma} \\
\sigma\end{array}$ & 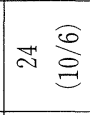 & $\exists \stackrel{\overbrace{}}{ت}$ & $\Rightarrow \frac{\frac{F}{10}}{10}$ & $\approx \underset{\infty}{\infty} \frac{\widehat{\infty}}{\infty}$ & 四 $\frac{\overline{0}}{0}$ & $8 \underset{\infty}{\stackrel{\infty}{\infty}}$ & $\stackrel{\alpha}{\sigma}$ & $0 \frac{\widehat{N}}{\sqrt[\omega]{b}}$ & $\begin{array}{ll}\infty & \overline{0} \\
\infty & 0 \\
0 & 0\end{array}$ \\
\hline 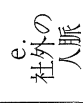 & $\approx \frac{\infty}{\infty}$ & 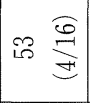 & $=\frac{10}{\frac{10}{0}}$ & 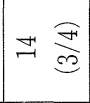 & $\because \frac{\frac{\gamma}{10}}{10}$ & $\exists \frac{\overparen{F}}{\nexists}$ & $\stackrel{\infty}{\rightarrow} \frac{\hat{10}}{10}$ & $i \frac{\alpha}{\theta}$ & $\Re \underset{\Im}{\stackrel{\widehat{9}}{\varrho}}$ & $\approx \frac{\widehat{d}}{\sigma}$ & $\approx \frac{a}{a}$ & $\sigma \frac{\widehat{m}}{\underline{b}}$ & 윰 $\frac{\overline{8}}{\frac{1}{10}}$ \\
\hline 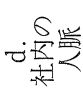 & of $\frac{0}{50}$ & $\stackrel{\stackrel{\sigma}{g}}{\stackrel{\overrightarrow{9}}{\Xi}}$ & $\infty \frac{\widehat{D}}{E}$ & $\approx \frac{\widehat{F}}{\theta}$ & $\infty \stackrel{\frac{\pi}{10}}{20}$ & 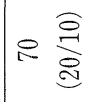 & 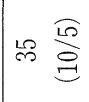 & F $\underset{f}{\stackrel{E}{\Xi}}$ & $i \frac{\infty}{\infty} \stackrel{\frac{\infty}{3}}{\stackrel{9}{g}}$ & 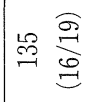 & $\stackrel{\infty}{\stackrel{\infty}{\infty \rho}}=$ & 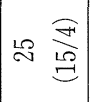 & $\begin{array}{ll}0 & \bar{\Xi} \\
8 & \stackrel{9}{\Xi} \\
& \Xi\end{array}$ \\
\hline & $\infty \frac{\mathbb{2}}{9}$ & 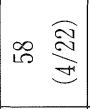 & Di $\frac{7}{\sqrt{10}}$ & 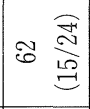 & $\infty \underset{\Xi}{\Xi}$ & $\sim \underset{\Xi}{\Xi}$ & $\therefore \frac{0}{3}$ & $\cong \frac{\widehat{L}}{\Omega}$ & 늠 $\frac{0}{0}$ & $\exists \frac{\widehat{10}}{a}$ & $\stackrel{\substack{\bar{G} \\
\infty}}{\underset{\infty}{0}}$ & m $\underset{\vec{a}}{\stackrel{a}{a}}$ & 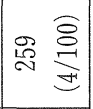 \\
\hline & $\stackrel{\partial}{\stackrel{\Xi}{\Xi}}$ & 유 $\frac{\widehat{S}}{\stackrel{S}{S}}$ & $\infty \underset{-1}{\stackrel{0}{a}}$ & $0 \stackrel{\widehat{\rho}}{\Xi}$ & $0 \frac{\widehat{\rho}}{\hat{c}}$ & $+\underset{\Xi}{\Xi}$ & $\Rightarrow \frac{0}{\infty}$ & $\approx \frac{0}{\infty}$ & $\approx \frac{\widehat{I}}{\sqrt[3]{3}}$ & 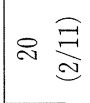 & $\llcorner\stackrel{\infty}{\vec{\infty}}$ & $0 \stackrel{\widehat{\rho}}{\frac{\widehat{\rho}}{0}}$ & 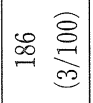 \\
\hline & $=\frac{\partial}{\partial}$ & 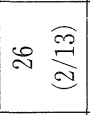 & 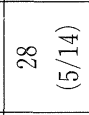 & $\underset{\sim}{\stackrel{\Xi}{\Theta}}$ & $\forall \frac{\widehat{I}}{\sqrt{d}}$ & $\stackrel{0}{\stackrel{0}{10}}$ & $\infty \frac{\widehat{\partial}}{\sqrt{d}}$ & $\leadsto \frac{\mathbb{s}}{\sigma}$ & 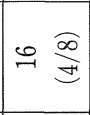 & $\approx \underset{\Theta}{\stackrel{\Xi}{\Theta}}$ & 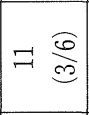 & 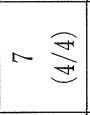 & 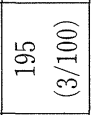 \\
\hline & 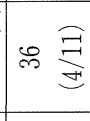 & 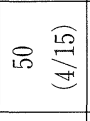 & $\therefore \stackrel{0}{\nexists}$ & $+\underset{\Xi}{\Xi}$ & $\infty \frac{\widehat{a}}{d}$ & $\sigma \frac{\widehat{\rho}}{\frac{\rho}{0}}$ & $0 \frac{\widehat{J}}{\mathrm{~d}}$ & 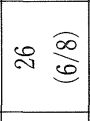 & 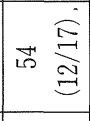 & 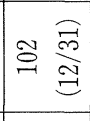 & 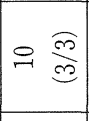 & $\sim \stackrel{\overparen{\Xi}}{\Xi}$ & 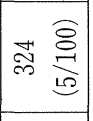 \\
\hline 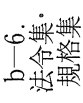 & $-\frac{\hat{\theta}}{\varrho}$ & $\sim \stackrel{\partial}{\partial}$ & $\sim \stackrel{\frac{\rho}{\rho}}{\varrho}$ & $\sim \frac{\widehat{\rho}}{\rho}$ & 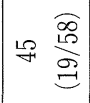 & $0 \frac{\widehat{\infty}}{\sqrt[d]{d}}$ & $-\frac{\hat{\theta}}{\Theta}$ & 0 o & o $\frac{\hat{o}}{\hat{e}}$ & $\sim \stackrel{\hat{\sigma}}{\vec{\theta}}$ & $0 \frac{\hat{a}}{0}$ & $\sim \frac{\partial}{\partial}$ & 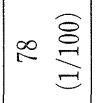 \\
\hline 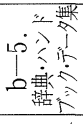 & 웅 & 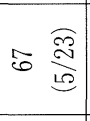 & 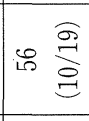 & $\infty \underset{\vec{\Xi}}{\stackrel{\bar{\Xi}}{\Xi}}$ & 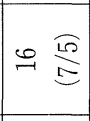 & $\stackrel{\infty}{\frac{0}{0}}$ & 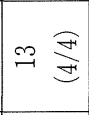 & 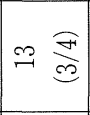 & $\Rightarrow \frac{\vec{F}}{a}$ & 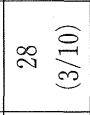 & $\stackrel{\infty}{\sim} \underset{\omega}{0}$ & $+\underset{d}{\stackrel{a}{a}}$ & m \\
\hline 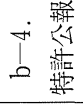 & $\Rightarrow \stackrel{E}{E}$ & $\sigma \stackrel{0}{\stackrel{10}{\Xi}}$ & $\sim \stackrel{\nexists}{\Xi}$ & 吾 $\frac{\mathbb{E}}{\stackrel{E}{c}}$ & $0 \frac{\bar{\partial}}{e}$ & o $\frac{\hat{a}}{\hat{\theta}}$ & $+\stackrel{\widehat{\vartheta}}{\Xi}$ & $-\begin{array}{ll}\frac{1}{0} \\
0\end{array}$ & $\infty \stackrel{\widehat{\vartheta}}{\Xi}$ & $-\frac{\bar{z}}{\varrho}$ & $-\frac{\hat{a}}{\hat{\theta}}$ & $-\rightarrow \stackrel{\vec{\Xi}}{\Xi}$ & 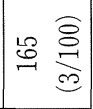 \\
\hline$\dot{\rho}^{\dot{m}}$ & $\exists \underset{\exists}{\stackrel{E}{S}}$ & 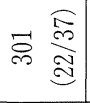 & 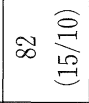 & $0 \underset{0}{\stackrel{a}{a}}$ & $\approx \stackrel{\widehat{N}}{\Xi}$ & $\approx \frac{\widehat{m}}{\infty}$ & 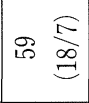 & $8 \stackrel{\infty}{\stackrel{\infty}{e}}$ & 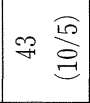 & F $\frac{10}{10}$ & $\stackrel{\circ}{\stackrel{\rho}{s}}$ & $\leadsto \underset{\infty}{\stackrel{a}{\infty}}$ & 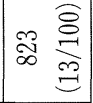 \\
\hline & 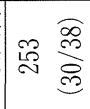 & 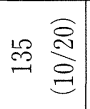 & $g \frac{0}{5}$ & 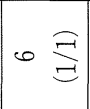 & 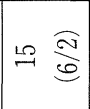 & $g \frac{\widehat{\rho}}{\omega}$ & F $\frac{\pi}{2}$ & 율 & $=\stackrel{\widehat{m}}{\nexists}$ & 아 $\frac{2}{6}$ & $\mathscr{D} \underset{\infty}{\stackrel{F}{\infty}}$ & $\exists \underset{\infty}{\stackrel{\widehat{N}}{\infty}}$ & 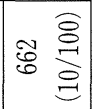 \\
\hline 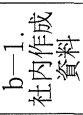 & F $\frac{\hat{\theta}}{\sqrt{60}}$ & 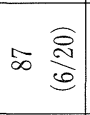 & F $\frac{\widehat{G}}{\sigma}$ & $\approx \frac{0}{0}$ & $\vec{\sigma} \frac{\widehat{D}}{\sigma}$ & 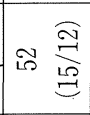 & $g \frac{\widehat{\sigma}}{\theta}$ & ন $\frac{\widehat{\theta}}{\Theta}$ & $\stackrel{0}{\sim} \frac{\hat{0}}{0}$ & 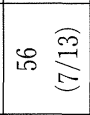 & $\approx \frac{\widehat{L}}{\Theta}$ & $\exists \underset{\infty}{\widehat{\infty}}$ & 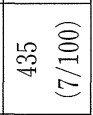 \\
\hline 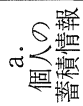 & $\& \underset{\Xi}{\stackrel{3}{\Xi}}$ & 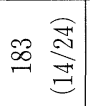 & $8 \stackrel{\frac{\sigma}{\sigma}}{\Theta}$ & $\vec{m} \underset{\infty}{\frac{\vec{F}}{\infty}}$ & 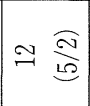 & 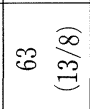 & $\approx \stackrel{\overbrace{}}{\stackrel{\sigma}{\varrho}}$ & 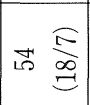 & $\vec{\omega} \underset{\Xi}{E}$ & 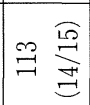 & $\approx \frac{\widehat{F}}{\sigma}$ & $\vec{\nabla} \underset{\vec{\Xi}}{\stackrel{\widehat{\Xi}}{\Xi}}$ & 일 \\
\hline 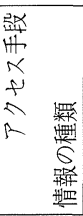 & 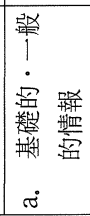 & 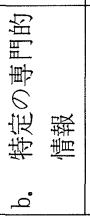 & 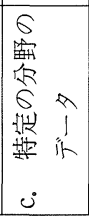 & 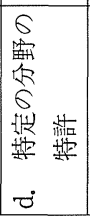 & 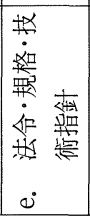 & 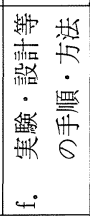 & 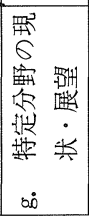 & 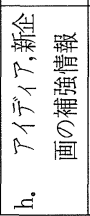 & 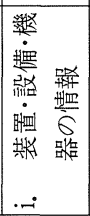 & 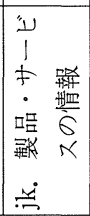 & 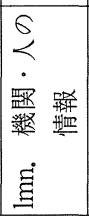 & 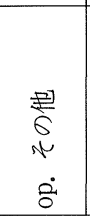 & fling \\
\hline
\end{tabular}


率（表 18 の最右欄）は $50 \%$ 前後で大きな開き はない。すなわち, 求める情報の種類に拘らず, 1 回のアクセス行動で平均 2 通り弱のアクセス 手段を用い，その約半分に満足を得たという図 式になる。

（2）社内の一次資料は，それぞれの得意の情報分 野での満足率は高いが，それ以外の分野で利用
される時は低いということがわかる。すなわち， 新聞・一般図書は「基礎的・一般的情報」を， 専門誌は「特定の専門情報」を，特許公報は「特 許情報」を，辞典・ハンドブック類は「特定分 野のデー夕」を，法令集・規格集は「法令，規 格，技術指針」を，カタログ・パンフレット類 は「製品・サービスの情報」を求めるためのア

表 16 情報の種類別のよく利用されるアクセス手段

\begin{tabular}{|c|c|c|c|c|c|}
\hline \multirow{2}{*}{ 情報の種類 } & \multicolumn{5}{|c|}{ アクセス手段(累計\%が $50 \%$ までの手段) } \\
\hline & 第 1 位 & 第 2 位 & 第 3 位 & 第 4 位 & 第 5 位 \\
\hline a. 基礎的 - 一般的情報 & $\begin{array}{r}\text { 新聞・図書 } \\
30 \%\end{array}$ & $\begin{array}{l}\text { 専門誌 } \\
\qquad 17 \%\end{array}$ & $\begin{array}{r}\text { 個人蓄積情報 } \\
11 \%\end{array}$ & & \\
\hline b。 特定の専門的情報 & $\begin{array}{l}\text { 専門誌 } \\
22 \%\end{array}$ & $\begin{array}{r}\text { 個人蓄積情報 } \\
14 \%\end{array}$ & $\begin{array}{r}\text { 新聞・図書 } \\
10 \%\end{array}$ & $\begin{array}{l}\text { 社内人脈 } \\
10 \%\end{array}$ & \\
\hline c. 特定分野のデー夕 & $\begin{array}{l}\text { 専門誌 } \\
15 \%\end{array}$ & $\begin{array}{r}\text { 個人蓄積情報 } \\
13 \%\end{array}$ & $\begin{array}{r}\text { ハンドブック等 } \\
10 \%\end{array}$ & $\begin{array}{r}\text { 社内資料 } \\
9 \%\end{array}$ & $\begin{array}{r}\text { 新聞・図書 } \\
7 \%\end{array}$ \\
\hline d. 特定分野の特許情報 & $\begin{array}{r}\text { 特許公報 } \\
30 \%\end{array}$ & $\begin{array}{r}\text { 社外 } \mathrm{DB} \\
15 \%\end{array}$ & $\begin{array}{r}\text { 担当部門 } \\
\qquad 9 \%\end{array}$ & & \\
\hline $\begin{array}{l}\text { e. 法令・規格・技術指針 } \\
\text { に関する情報 }\end{array}$ & $\begin{array}{r}\text { 法令集等 } \\
19 \%\end{array}$ & $\begin{array}{r}\text { 社内人脈 } \\
15 \%\end{array}$ & $\begin{array}{r}\text { 担当部門 } \\
10 \%\end{array}$ & $\begin{array}{r}\text { 社内資料 } \\
9 \%\end{array}$ & \\
\hline $\begin{array}{ll}\text { f. } & \text { 実験・設計の手順・方 } \\
& \text { 法に関する情報 }\end{array}$ & $\begin{array}{l}\text { 社内人脈 } \\
20 \%\end{array}$ & $\begin{array}{r}\text { 個人蓄積情報 } \\
18 \%\end{array}$ & $\begin{array}{r}\text { 社内資料 } \\
15 \%\end{array}$ & & \\
\hline $\begin{array}{l}\text { g. 特定分野の現状・展 } \\
\text { 望に関する情報 }\end{array}$ & $\begin{array}{l}\text { 専門誌 } \\
18 \%\end{array}$ & $\begin{array}{r}\text { 新聞・図書 } \\
15 \%\end{array}$ & $\begin{array}{r}\text { 社内人脈 } \\
10 \%\end{array}$ & $\begin{array}{r}\text { 個人蓄積情報 } \\
10 \%\end{array}$ & \\
\hline $\begin{array}{l}\text { h. アイディア・新企画 } \\
\text { の補強情報 }\end{array}$ & $\begin{array}{l}\text { 専門誌 } \\
\qquad 16 \%\end{array}$ & $\begin{array}{r}\text { 個人蓄積情報 } \\
13 \%\end{array}$ & $\begin{array}{l}\text { 社内人脈 } \\
12 \%\end{array}$ & $\begin{array}{r}\text { 新聞・図書 } \\
11 \%\end{array}$ & \\
\hline $\begin{array}{l}\text { i. 装置・設備・機器に関 } \\
\text { する情報 }\end{array}$ & $\begin{array}{r}\text { 社内人脈 } \\
13 \%\end{array}$ & $\begin{array}{l}\text { カタログ.パン } \\
\text { フレット } 12 \%\end{array}$ & $\begin{array}{r}\text { 個人蓄積情報 } \\
11 \%\end{array}$ & $\begin{array}{l}\text { 専門誌 } \\
\qquad 10 \%\end{array}$ & $\begin{array}{l}\text { 社外人脈 } \\
10 \%\end{array}$ \\
\hline $\begin{array}{l}\mathrm{ik} \text {. 製品・サービスに関 } \\
\text { する情報 }\end{array}$ & $\begin{array}{r}\text { 社内人脈 } \\
16 \%\end{array}$ & $\begin{array}{r}\text { 個人蓄積情報 } \\
14 \%\end{array}$ & $\begin{array}{l}\text { カタログ・パン } \\
\text { フレット } 12 \%\end{array}$ & $\begin{array}{r}\text { 社外人脈 } \\
9 \%\end{array}$ & \\
\hline $\begin{array}{ll}\text { lmn。 組織・人に関する } \\
\\
\text { 情報 }\end{array}$ & $\begin{array}{r}\text { 社内人脈 } \\
15 \%\end{array}$ & $\begin{array}{r}\text { 担当部門 } \\
\qquad 9 \%\end{array}$ & $\begin{array}{r}\text { 個人蓄積情報 } \\
9 \%\end{array}$ & $\begin{array}{r}\text { 社外人脈 } \\
9 \%\end{array}$ & $\begin{array}{r}\text { 新聞・困書 } \\
8 \%\end{array}$ \\
\hline 体 & $\begin{array}{l}\text { 専門誌 } \\
13 \%\end{array}$ & $\begin{array}{r}\text { 個人蓄積情報 } \\
12 \%\end{array}$ & $\begin{array}{l}\text { 社内人脈 } \\
11 \%\end{array}$ & $\begin{array}{r}\text { 新聞・図書 } \\
10 \%\end{array}$ & $\begin{array}{r}\text { 社内資料 } \\
7 \%\end{array}$ \\
\hline
\end{tabular}


クセスでの満足率が比較的高い。

（3）3.4で既に述べたが，個人蓄積情報や社内一 次資料（新聞・困書，専門誌）は利用度は高い が満足率（「当たる」確率）は比較的低いのに封 し，社外データベース，社内情報担当部門，内 外のセミナ一等の情報サ一ビス手段は，利用度 は低いものの満足率は高い。内外の人脈の利用 は，利用度，満足率とも高いと言之る。この傾
向をわかりやすく把握するために,表 18 に基づ き，情報の種類ごとに，

・利用度も満足率も高いアクセス手段

・利用度は高いが満足率はそれほど高くない アクセス手段

・利用度は低いが満足率の高いアクセス手段 を挙げたのが表 19 である。

表 17 アクセス手段ごとによく利用される情報の種類

\begin{tabular}{|c|c|c|c|c|}
\hline \multirow{2}{*}{ アクセス手段 } & \multicolumn{4}{|c|}{ 情報の種類 (累系\%が $50 \%$ まで) } \\
\hline & 第 1 位 & 第 2 位 & 第 3 位 & 第 4 位 \\
\hline a. 個人の貯蓄情報 & $\begin{array}{r}\text { 専門情報 } \\
24 \%\end{array}$ & \begin{tabular}{|} 
製品情報 \\
$15 \%$
\end{tabular} & $\begin{array}{r}\text { 一般情報 } \\
13 \%\end{array}$ & \\
\hline $\mathrm{b}-1$. 社内作成資料 & $\begin{array}{r}\text { 専門情報 } \\
20 \%\end{array}$ & \begin{tabular}{|c|} 
製品情報 \\
$13 \%$
\end{tabular} & \begin{tabular}{|r|} 
実験・設計情 \\
報 $\quad 12 \%$
\end{tabular} & データ $11 \%$ \\
\hline $\mathrm{b}-2$. 新聞・一般図書 & $\begin{array}{r}\text { 一般情報 } \\
38 \%\end{array}$ & \begin{tabular}{|l|} 
専門情報 \\
$20 \%$ \\
\end{tabular} & & \\
\hline $\mathrm{b}-3$. 専門誌 & \begin{tabular}{|r|} 
専門情報 \\
$37 \%$
\end{tabular} & 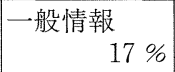 & & \\
\hline b-4。特許公報 & \begin{tabular}{|} 
特許情報 \\
$77 \%$
\end{tabular} & & & \\
\hline $\begin{aligned} \mathrm{b}-5 . \text { 辞典・ハンドブ } \\
\text { ック・データ集 }\end{aligned}$ & \begin{tabular}{|r|} 
専門情報 \\
$23 \%$ \\
\end{tabular} & データ $19 \%$ & \begin{tabular}{|r|} 
一般情報 \\
$16 \%$ \\
\end{tabular} & \\
\hline b一 -6. 法令集 - 規格集 & $\begin{array}{r}\text { 法令・規格 } \\
58 \%\end{array}$ & & & \\
\hline $\begin{array}{c}\mathrm{b}-7 . \text { カタタクグ・パン } \\
\text { フレット }\end{array}$ & \begin{tabular}{|} 
製品情報 \\
$31 \%$
\end{tabular} & \begin{tabular}{r|} 
装置・機器 \\
$17 \%$
\end{tabular} & $\begin{array}{r}\text { 専門情報 } \\
15 \%\end{array}$ & \\
\hline $\begin{array}{l}\mathrm{b}-8 \text { 。社内データベー } \\
\text { ス }\end{array}$ & データ $14 \%$ & \begin{tabular}{|r|} 
専門情報 \\
$13 \%$ \\
\end{tabular} & \begin{tabular}{|r|} 
特許情報 \\
$12 \%$ \\
\end{tabular} & $\begin{array}{r}\text { 製品情報 } \\
11 \% \\
\end{array}$ \\
\hline$c-1$. 社外二次資料 & \begin{tabular}{|r|} 
専門情報 \\
$25 \%$ \\
\end{tabular} & \begin{tabular}{r|} 
装置・機器 \\
$12 \%$ \\
\end{tabular} & \begin{tabular}{|r|} 
一般情報 \\
$11 \%$ \\
\end{tabular} & $\begin{array}{r}\text { 製品情報 } \\
11 \% \\
\end{array}$ \\
\hline $\begin{array}{c}c-2 \text {. 社外データベー } \\
\text { ス }\end{array}$ & \begin{tabular}{|} 
特許情報 \\
$24 \%$
\end{tabular} & \begin{tabular}{|r|} 
専門情報 \\
$22 \%$
\end{tabular} & デー夕 $11 \%$ & \\
\hline $\begin{array}{ll}\text { d. 社内人脈による生 } \\
\text { 情報 }\end{array}$ & \begin{tabular}{|r|} 
製品情報 \\
$19 \%$ \\
\end{tabular} & \begin{tabular}{|r|} 
専門情報 \\
$19 \%$ \\
\end{tabular} & \begin{tabular}{|l|} 
実験・設計情 \\
報 \\
列
\end{tabular} & $\begin{array}{l}\text { 装置·機器 } 8 \% \\
\text { 組織・人 } 8 \% \\
\end{array}$ \\
\hline $\begin{array}{ll}\text { e. 社外人脈による生 } \\
\text { 情報 }\end{array}$ & \begin{tabular}{|c|} 
製品情報 \\
$21 \%$ \\
\end{tabular} & \begin{tabular}{|r|} 
専門情報 \\
$16 \%$ \\
\end{tabular} & \begin{tabular}{r|} 
装置・機器 \\
$13 \%$ \\
\end{tabular} & \\
\hline $\begin{array}{l}\text { f. 社内担当部門を通 } \\
\text { じた情報 }\end{array}$ & \begin{tabular}{|r|} 
製品情報 \\
$18 \%$ \\
\end{tabular} & \begin{tabular}{|c|} 
専門情報 \\
$16 \%$ \\
\end{tabular} & \begin{tabular}{r|} 
装置・機器 \\
$10 \%$ \\
\end{tabular} & $\begin{array}{l}\text { デー夕 } 9 \% \\
\text { 特許情報 } 9 \%\end{array}$ \\
\hline 全 & \begin{tabular}{|c|} 
専門情報 \\
$21 \%$
\end{tabular} & $\begin{array}{r}\text { 一般情報 } \\
13 \% \%\end{array}$ & $\begin{array}{r}\text { 製品情報 } \\
13 \% \\
\end{array}$ & データ $9 \%$ \\
\hline
\end{tabular}




\begin{tabular}{|c|c|c|c|c|c|c|c|c|c|c|c|c|c|c|}
\hline$t$ & 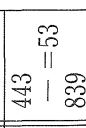 & $\begin{array}{c}\text { in } \\
\text { II } \\
\text { है। }\end{array}$ & 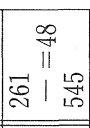 & 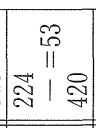 & 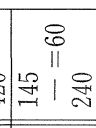 & 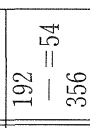 & 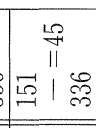 & 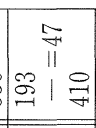 & 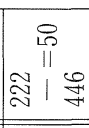 & 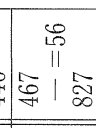 & $s$ & 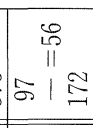 & 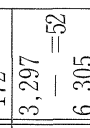 & j \\
\hline 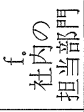 & 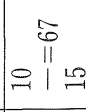 & 总 & 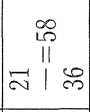 & 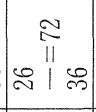 & 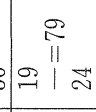 & 点 & $4=$ & 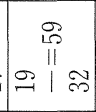 & 要 & 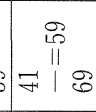 & B. & & 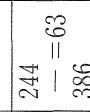 & \\
\hline & & & il & $\begin{array}{c}\infty \\
\infty \\
\approx \\
\approx\end{array}$ & 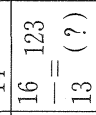 & $\stackrel{ }{\pi}$ & 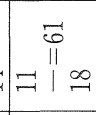 & 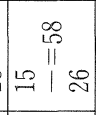 & 要 & $=\begin{array}{c}\vec{\infty} \\
11 \\
\infty\end{array}$ & 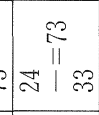 & & 告 & \\
\hline & & $\begin{array}{l}\infty \\
11 \\
11 \\
21 \\
2\end{array}$ & $\begin{array}{c}8 \\
i 1 \\
211\end{array}$ & $\hat{\|}$ & 象 & 党 & 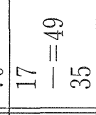 & 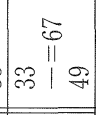 & 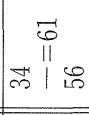 & 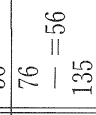 & $s$ & \begin{tabular}{c}
$\infty$ \\
0 \\
\hdashline 11 \\
$=12$
\end{tabular} & 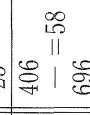 & \\
\hline & $\begin{array}{c}\stackrel{\infty}{7} \\
11 \\
\sim\end{array}$ & 点 & 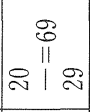 & 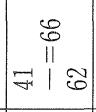 & & & هـ & $\mid \begin{array}{ll}2 & 2 \\
\pi & 11\end{array}$ & م & $=\begin{array}{c}2 \\
\pi 1 \\
=\end{array}$ & 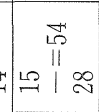 & & 要 & \\
\hline 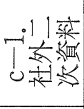 & & 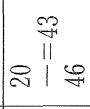 & 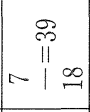 & & & & 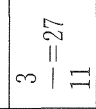 & 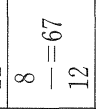 & \begin{aligned} & \multicolumn{1}{c}{} \\
& $\stackrel{1}{1} \\
= & 1\end{aligned}$ & 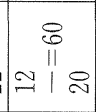 & $\begin{array}{c}\pi \\
\pi \\
+1 \\
+1\end{array}$ & & $\begin{array}{ll} & F \\
& \| 1 \\
21 & 0\end{array}$ & \\
\hline & & 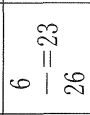 & 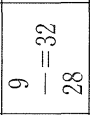 & 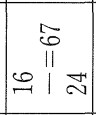 & & 藏 & & $\begin{array}{c}\vec{\pi} \\
+\| \Omega\end{array}$ & 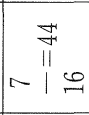 & $\begin{array}{c}0 \\
11 \\
=1 \\
=1\end{array}$ & $\begin{array}{c}\infty \\
11 \\
+1=\end{array}$ & & 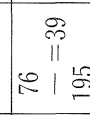 & \\
\hline & $\begin{array}{ll}\pi \\
\pi \\
1 \pi\end{array}$ & $\begin{array}{ll}\infty \\
11 \\
0 & \infty\end{array}$ & 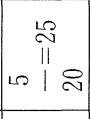 & & & & & $\begin{array}{c}\pi \\
\pi \\
-12\end{array}$ & $\begin{array}{c}\vec{\pi} \\
\approx\end{array}$ & $\begin{array}{c}8 \\
0 \\
11 \\
0 \\
0\end{array}$ & & & 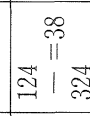 & \\
\hline 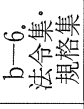 & & & & & $\begin{array}{cc}\overrightarrow{5} \\
\approx & 11 \\
\approx & 1\end{array}$ & & & & & & & & 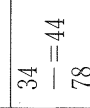 & \\
\hline & $\begin{array}{c}\vec{F} \\
\text { II } \\
1\end{array}$ & 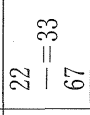 & 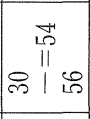 & & 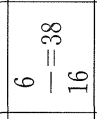 & 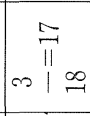 & $\begin{array}{c}\vec{\pi} \\
\|\| \\
+\|\end{array}$ & $\begin{array}{c}\vec{\pi} \\
\| \\
+\| m\end{array}$ & $\mid \begin{array}{ll}\underbrace{2} \\
\|\end{array}$ & 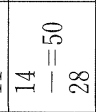 & 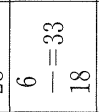 & & 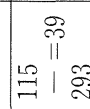 & \\
\hline 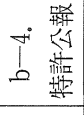 & $\mid \begin{array}{ll}11 \\
11 \\
10\end{array}$ & & & 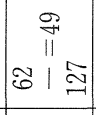 & & & & & & & & & 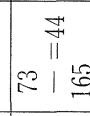 & \\
\hline 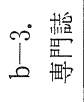 & $\begin{array}{c}9 \\
11 \\
81\end{array}$ & 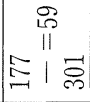 & 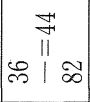 & & $\begin{array}{lll}\mathbb{O} & \\
11 & 1\end{array}$ & 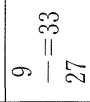 & in & 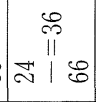 & 管 & $\begin{array}{c}\text { 유 } \\
\text { 인 }\end{array}$ & 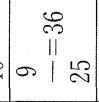 & 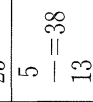 & 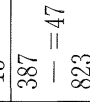 & \\
\hline 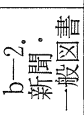 & $\begin{array}{l}8 \\
0 \\
0 \\
0 \\
0\end{array}$ & $\begin{array}{c}\stackrel{8}{7} \\
\text { II } \\
01\end{array}$ & 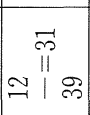 & & 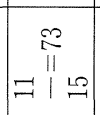 & 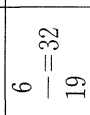 & 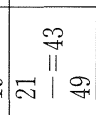 & $\begin{array}{c}8 \\
\text { II } \\
\Rightarrow \\
=1\end{array}$ & $\begin{array}{l}i 0 \\
i 1 \\
01\end{array}$ & $\stackrel{10}{\mathbb{1}}$ & $\begin{array}{l}9 \\
11 \\
118 \\
=18\end{array}$ & م. & 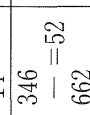 & \\
\hline 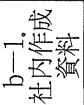 & 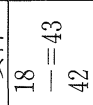 & 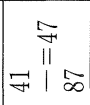 & $\stackrel{g}{\mathbb{7}}$ & . & 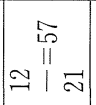 & 总 & 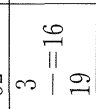 & 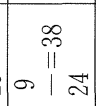 & 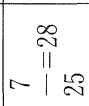 & 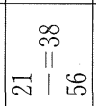 & {$\left[\begin{array}{c}F \\
\mathbb{I I} \\
0\end{array}\right.$} & $=\begin{array}{l}\pi \\
0\end{array}$ & 焉 & s. \\
\hline 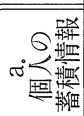 & 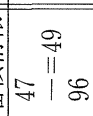 & \begin{tabular}{cc}
$\hat{0}$ \\
$\mathbb{N}$ \\
$\infty$ & $\stackrel{\infty}{\infty}$ \\
\hdashline & 1
\end{tabular} & 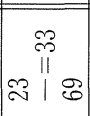 & $\mid \begin{array}{c}\infty \\
\mathbb{\pi} \\
m \\
m\end{array}$ & $\begin{array}{lll} & 0 \\
& 11 \\
0 & 1 & 7\end{array}$ & 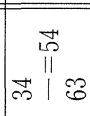 & $\stackrel{m}{\pi}$ & 藏 & 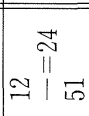 & $\begin{array}{c}\vec{\pi} \\
\| \\
\infty \\
\infty\end{array}$ & $\begin{array}{ll}\infty & \infty \\
0 & \pi\end{array}$ & $\stackrel{\Re}{\#}$ & $\mid \begin{array}{c}\infty \\
\mathbb{0} \\
\|\end{array}$ & \\
\hline 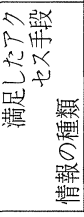 & 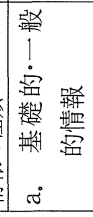 & 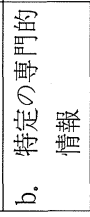 & 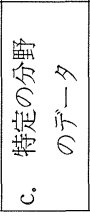 & 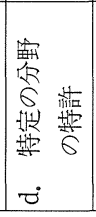 & 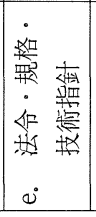 & 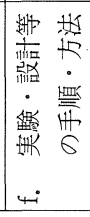 & 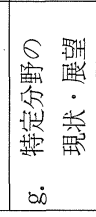 & 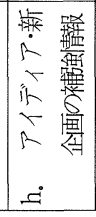 & 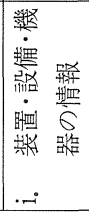 & 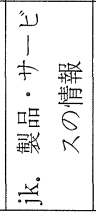 & 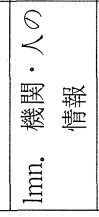 & \begin{tabular}{l}
$\frac{9}{2}$ \\
\multirow{2}{*}{} \\
\multirow{2}{0}{} \\
$\dot{0}$
\end{tabular} & 霖 & \\
\hline
\end{tabular}




\section{5。モニター調查の結果一その3.諸項目 間の関係}

ここでは，4で分析した情報の種類とアクセス 手段の間の関係以外の項目間関係を，クロス集計 の結果により分析する。

\section{1 情報の種類と諸項目間の関係}

（1）情報の種類ごとの入手契機と入手目的

図 1 と図 2 はそれぞれ，入手しようとした情報 の種類ごとに，入手の契機と目的を集計したもの である。どちらの図も，それぞれの帯グラフの幅 は，当該の情報へのアクセス度数に比例している。 したがって個々の区画の面積は，当該の情報に当 該の契機（または目的）によりアクセスした度数

表 19 情報の種類ごとの利用アクセス手段の特徵

\begin{tabular}{|c|c|c|c|}
\hline \multirow[b]{2}{*}{ 情報の種類 } & \multicolumn{3}{|c|}{ アクセス手段 } \\
\hline & $\begin{array}{l}\text { 利用度が高く, 満足 } \\
\text { 度も高い }\end{array}$ & $\begin{array}{l}\text { 利用度は高いが, 満 } \\
\text { 足度は余り高くない }\end{array}$ & $\begin{array}{l}\text { 利用度は低いが, 満 } \\
\text { 足度は高い }\end{array}$ \\
\hline $\begin{array}{l}\text { a. 基礎的 - 一般的 } \\
\text { 情報 }\end{array}$ & 新聞・図書 & $\begin{array}{l}\text { 専門誌 } \\
\text { 個人蓄積情報 }\end{array}$ & 社外人脈，担当部門 \\
\hline $\begin{array}{l}\text { b. 特定の専門的情 } \\
\text { 報 }\end{array}$ & 専門誌，社内人脈 & $\begin{array}{l}\text { 新聞・図書 } \\
\text { 個人蓄積情報 }\end{array}$ & $\begin{array}{l}\text { 社外データベース } \\
\text { 社外人脈 }\end{array}$ \\
\hline $\begin{array}{l}\text { c. 特定分野のデー } \\
\text { 夕 }\end{array}$ & $\begin{array}{l}\text { ハンドブック } \\
\text { 社内資料 }\end{array}$ & $\begin{array}{l}\text { 専門誌 } \\
\text { 個人蓄積情報 }\end{array}$ & $\begin{array}{l}\text { 社内人脈, 担当部門 } \\
\text { 社外データベース }\end{array}$ \\
\hline $\begin{array}{l}\text { d. 特定分野の特許 } \\
\text { 情報 }\end{array}$ & 社外データベース & 特許公報 & 担当部門 \\
\hline $\begin{array}{l}\text { e. 法令·規格·技術指 } \\
\text { 針に関わる情報 }\end{array}$ & & 法令集等，社内人脈 & 社外人脈，担当部門 \\
\hline $\begin{array}{l}\text { f. 実験·設計の手順・ } \\
\text { 方法に関方る情報 }\end{array}$ & 社内人脈，社内資料 & 個人蓄積情報 & 社外人脈 \\
\hline $\begin{array}{l}\text { g. 特定分野の現状・ } \\
\text { 展望に関する情報 }\end{array}$ & 専門誌, 社内人脈 & $\begin{array}{l}\text { 新聞・図書 } \\
\text { 個人蓄積情報 }\end{array}$ & 社外人脈，担当部門 \\
\hline $\begin{array}{l}\text { h. アイディア・新 } \\
\text { 企画の補強情報 }\end{array}$ & 社内人脈 & $\begin{array}{l}\text { 専門誌，新聞・図書 } \\
\text { 個人蓄樍情報 }\end{array}$ & 社外人脈，担当部門 \\
\hline $\begin{array}{ll}\text { i。 } & \text { 装置・設備·機器 } \\
& \text { に関する情報 }\end{array}$ & $\begin{array}{l}\text { 社内人脈，社外人脈 } \\
\text { カタログ・パンフレ } \\
\text { ット }\end{array}$ & 個人蓄積情報 & $\begin{array}{l}\text { 社外二次資料 } \\
\text { 社外データベース }\end{array}$ \\
\hline $\begin{aligned} \mathrm{jk} . & \text { 製品・サービス } \\
& \text { に関する情報 }\end{aligned}$ & $\begin{array}{l}\text { 社内人脈 } \\
\text { カタログ・パンフレ } \\
\text { ット }\end{array}$ & 個人蓄積情報 & 社外人脈, 新聞·図書 \\
\hline $\begin{array}{ll}\text { lmn。 } & \text { 組織・人に関 } \\
& \text { する情報 }\end{array}$ & 社内人脈 & & $\begin{array}{l}\text { 社外人脈，担当部門 } \\
\text { 新聞・図書 } \\
\text { 社外データベース }\end{array}$ \\
\hline
\end{tabular}


に比例する。

個々の情報の特徵は図から読み取れるので省略 するがむしろ，どの契機，どの目的においても， いろいろな情報が多角的に利用されていることに 注目したい。例えば，研究開発の現状や展望につ いての情報 $(\mathrm{g})$ や，あアイディアや新企画を裹 付け，補強する情報(h) は，企画段階に必要と思わ れ，事実その傾向は強いが，業務の実施や整理の 段階でも使われている。また，実施段階での利用 が中心のはずの実験の手順・方法 (f) や装置・機器
についての情報 (i)が企画段階でも使われている。

（2）必要性，期待度，緊急性との関係

ここでは，情報の種類ごとに，その必要性の程 度，的確な情報入手への期待度と実際に入手した 情報に対する満足度，入手の緊急度と実際に情報 入手に要した期間との関係を分析する。

これらの程度を定量的に示すために，各質問で の回答に対して表 20 のような得点值を与えた。そ して，それぞれの情報の種類ごとに，必要度，期 待度, 満足度, 緊急度, および入手時間に対する

表 20 各回答に対する得点值

(図 3, 図 7 を参照)

\begin{tabular}{|c|c|c|}
\hline 質 & 回 & 得 点 \\
\hline $\begin{array}{l} \\
\text { 惊 } \\
\text { 必幸 } \\
\text { 要手 } \\
\text { 性 }\end{array}$ & $\begin{array}{l}\text { 非常に高い } \\
\text { かなり高い } \\
\text { できれば入手したい } \\
\text { どちらでもよい }\end{array}$ & $\begin{array}{r}100 \\
75 \\
50 \\
25\end{array}$ \\
\hline 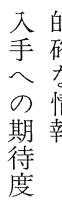 & $\begin{array}{l}\text { 大きく期待した } \\
\text { かなり期待した } \\
\text { 多少期待した } \\
\text { あまり期待しない } \\
\text { ほとんど期待しない }\end{array}$ & $\begin{array}{r}100 \\
80 \\
60 \\
40 \\
20\end{array}$ \\
\hline 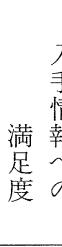 & $\begin{array}{l}\text { 非常に満足 } \\
\text { かなり満足 } \\
\text { 普通 } \\
\text { かなり不満 } \\
\text { ほとんど成果がなかった } \\
\text { まだ結果が得られていない }\end{array}$ & $\begin{array}{r}100 \\
75 \\
50 \\
25 \\
0 \\
0\end{array}$ \\
\hline 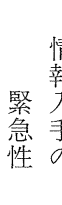 & $\begin{array}{l}\text { 即座に欲しい } \\
\text { 当日中に欲しい } \\
1 \text { 週間以内に欲しい } \\
1 \text { か以内に欲しい } \\
\text { それ以上でもよい }\end{array}$ & $\begin{array}{r}100 \\
90 \\
60 \\
30 \\
10\end{array}$ \\
\hline $\begin{array}{l}\text { 要情 } \\
\text { た幸 } \\
\text { た } \\
\text { 時手 } \\
\text { 間 }\end{array}$ & $\begin{array}{l}\text { その日のうち } \\
\text { 数日以内 } \\
1 \text { 週間以内 } \\
1 \text { 週間以上 } \\
\text { まだ結果が得られていない }\end{array}$ & $\begin{array}{r}100 \\
75 \\
50 \\
25 \\
0\end{array}$ \\
\hline
\end{tabular}


情報の種類

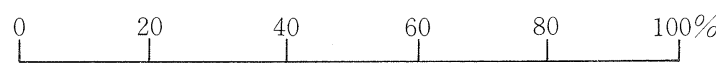

a. 基礎的

一般的情報

$(13.4 \%)$

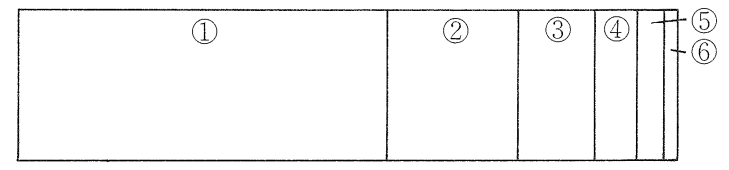

b. 専門的情報

(21.8\%)

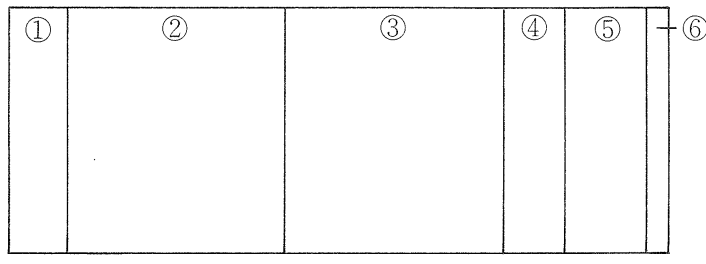

c. デー夕

$(8.2 \%)$

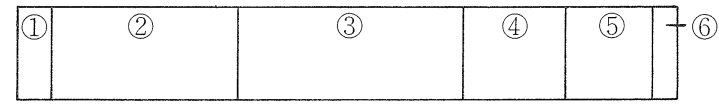

d. 特許情報

$(6.9 \%)$

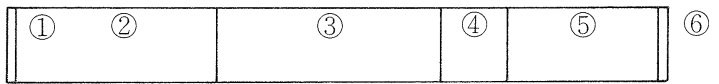

eo. 法規、指針、事故 対策情報 $(5.2 \%)$

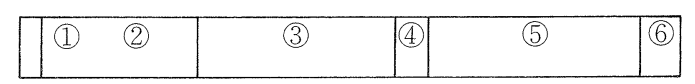

f. 実験等の手順・方法 (5.6\%)

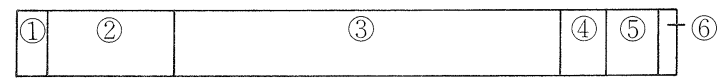

g. $\mathrm{R} \& \mathrm{D} の$ 現状・原望 $(4.7 \%)$

\begin{tabular}{|l|l|l|l|l|l|}
\hline (1) & (2) & (3) & (4) & (5) & (6) \\
\hline
\end{tabular}

h. アイディア・新企画の 裏付け情報 $(5.8 \%)$

i. 装置、機器の情報 $(6.8 \%)$

\begin{tabular}{|l|l|l|l|l|l|}
\hline (1) (2) & (3) & (4) & (5) & (6) \\
\hline
\end{tabular}

\begin{tabular}{|l|l|l|l|l|l|}
\hline (1) & (2) & (3) & (4) & (5) & (6) \\
\hline
\end{tabular}

$\mathrm{jk}$. 製品・サービスの 情報

$(13.7 \%)$

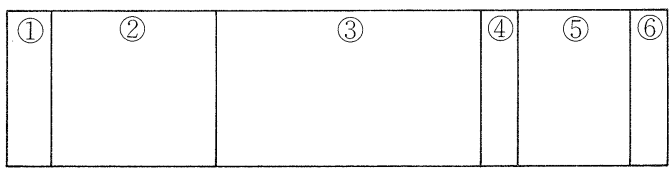

$\operatorname{lm} n$. 機関・人の情報

$(5.8 \%)$

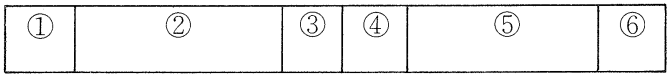

全 体 $(100 \%)$

\begin{tabular}{|c|c|c|c|c|}
\hline (1) & (2) & (3) & (4) & (5) \\
\hline
\end{tabular}

図 1 情報の種類ごとの利用契㙨 
情報の種類

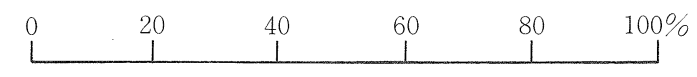

a. 基礎的

一般的情報

(12.6\%)

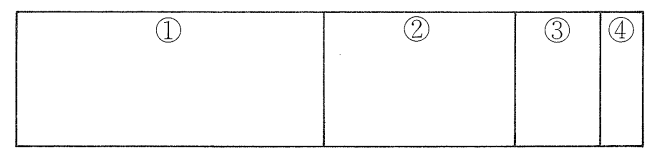

b. 専門的情報

$(22.5 \%)$

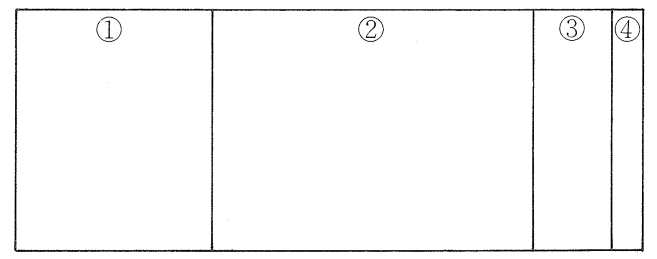

c. データ

$(8.4 \%)$

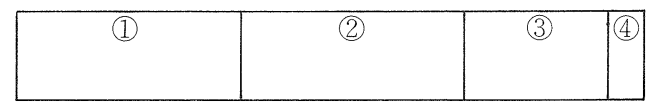

d. 特許情報

$(7.3 \%)$

eo. 法規、指針、事故 対策情報 $(5.2 \%)$

f. 実験等の手順・方法 $(5.9 \%)$

g. R\&Dの現状・展望 $(4.6 \%)$
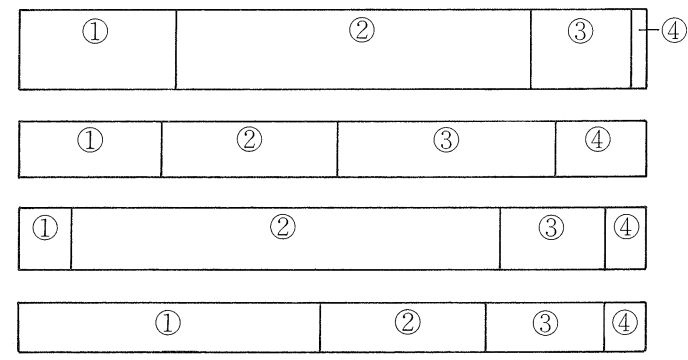

h. アイディア・新企画の 裏付情報 $(6.0 \%)$

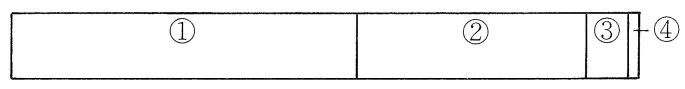

i. 装置・機器の情報 $(6.8 \%)$

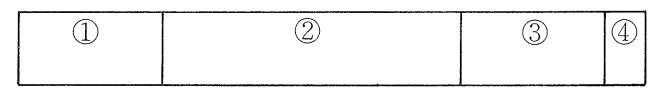

$\mathrm{jk}$. 製品、サービスの情報 $(13.5 \%)$

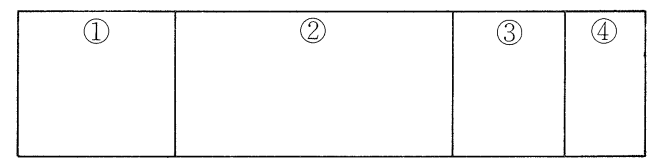

$\operatorname{lmn}$. 機関 ・人の情報 $(5.4 \%)$

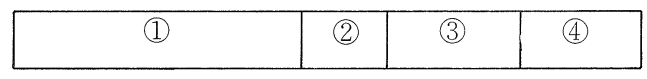

全 体 $(100 \%)$

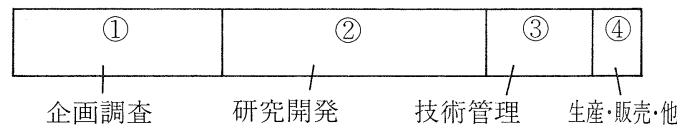

図 2 情報の種類ごとの利用目的 

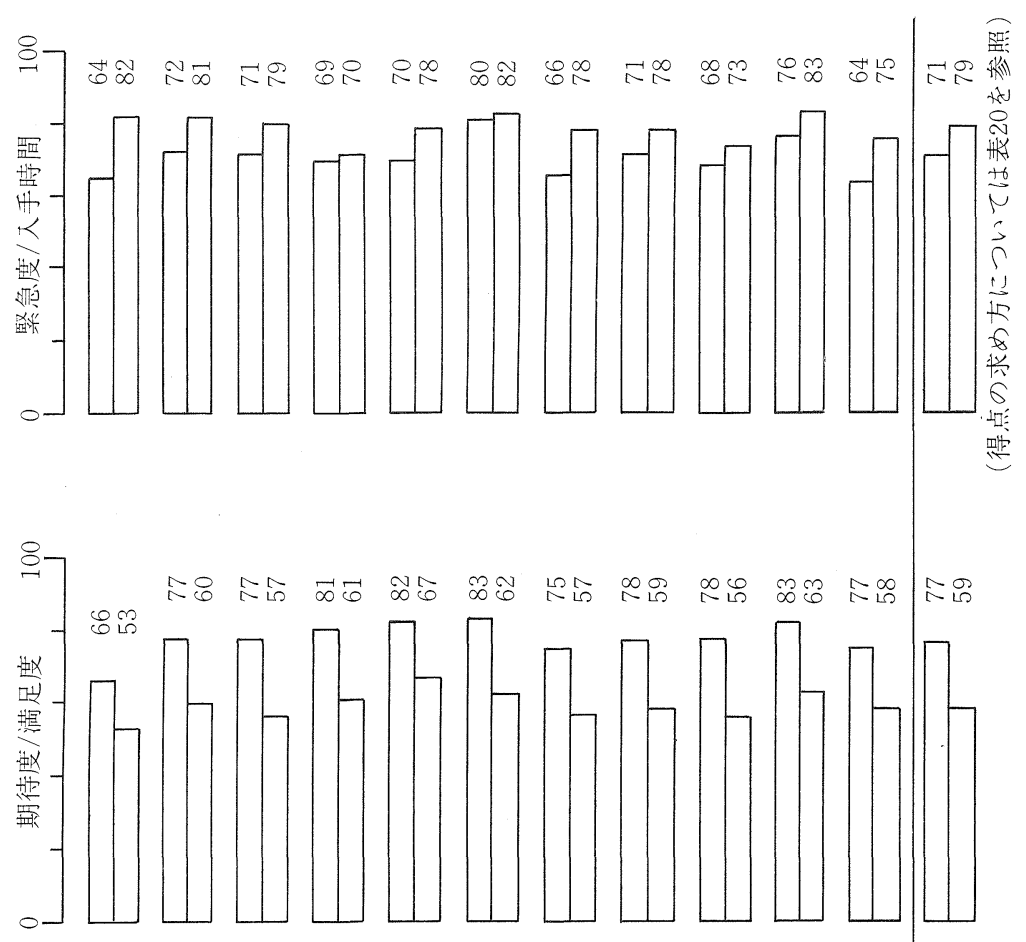

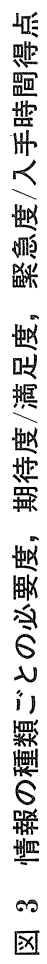

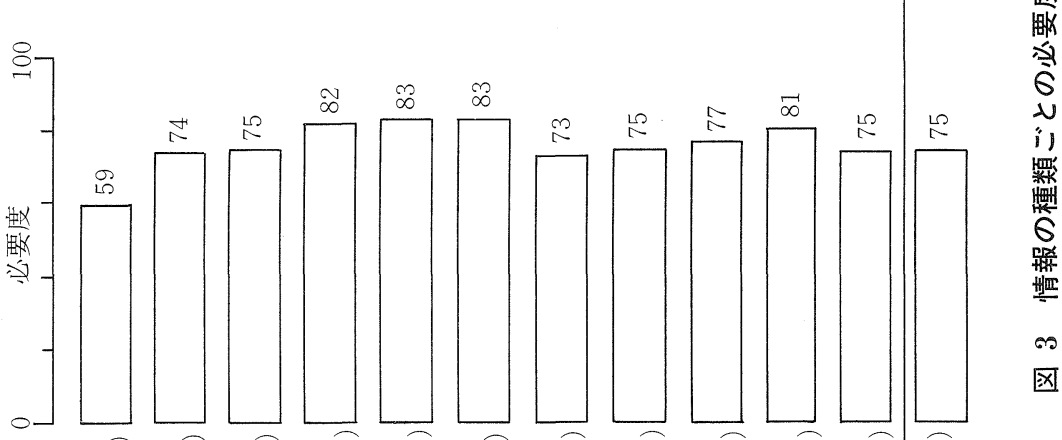




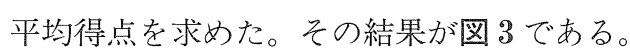
この特徵は次のようである。

(1)必要度, 期待度, 満足度に対する傾向は似て おり，特定的情報に対する得点が高く，一般 的情報に対しては低い。必要度と期待度の明 確な区別はなされていないものと思われる。

(2)緊急性の特に高い情報は，実験等で直接必要 な情報であり，これらについては入手時間の 得点も高い。しかし二，三項目を除いては， 緊急度と入手時間の間に強い相関は見られな い。

図 4 はこれを別の角度から示しており, 必要度, 期待度, 満足度, 緊急度, および入手時間の得点 值が高い回答だけをとった情報の種類別の分布 を，回答全体の分布と比較したものである。

\section{2 アクセス手段と諸項目間の関係}

（1）アクセス手段ごとの情報の入手契機と入手目 的

図 5 と図 6 は, 情報入手に用いたアクセス手段 ごとに,入手の契機と目的を集計したものである。 図 1 と図 2 の場合と同様に，これらの図の带グラ フの幅は, 当該アクセス手段の利用度数に比例し ているので，個々の区画の面積は相当する絶対度 数に比例することになる。また，図 5 と図 6 にお ける斜線部は，アクセスした手段のうち満足の得 られた手段を示す (3.4 参照)。

情報の種類と入手契機・入手目的との関係 (5.1 の(1)参照）のところで見たのと同様に，アクセス 手段の利用度も，入手契機，入手目的ごとの特徵 が見られる一方，どのアクセス手段もある契機， ある目的にのみ偏することなく，いろいろな局面 である程度利用されているのが印象的である。入 手契機別のアクセス手段の利用分布の異なる傾向 に比べて，入手目的別には，アクセス手段の利用 分布はより一様（図6の带グラフの長さの縦方向 のバラツキが小さい)である。つまり，企画調査， 研究開発，技術管理，生産販売のどの目的に使わ れるにしろ，利用されるアクセス手段の利用比に 大きな違いはない。
我々情報サービスに携うる者として興味の梁い 社外データベース，社内担当部門の利用の契機を 見ると，社内の上司・同僚，他部門からの要請に よってアクセスした度合が高い。このことはここ れらの利用のノウハウを特定の技術者が持ってお り，このような人に社内の他の人から依頼や相談 が持ちかけられることを暗示している。一方，社 内データベースや社外二次資料にはこの傾向はな く，研究者・技術者が自分で使う手段となってい る(利用度が高いということではないが)ようだ。 （2）必要性，期待度，緊急性との関係

情報の種類に対して分析した（5。1 (2)参照）の と同じように，使用したアクセス手段ごとの，必 要度, 期待度, 満足度, 緊急度, 入手時間の評価 を定量的に求めた。このため, 表 20 に示した各回 答に対する得点值の平均点を, アクセス手段ごと に求めた。結果を図 7 に示す。

このうち必要度と期待度の得点については，ア クセス手段そのものに対する評価というより，そ れに関係深い情報の種類に対する評価が反映して いるようにも思之る。しかし満足度に対する得点 は，そのアクセス手段に対するかなり直接的評価 が現れているようで興味深い。アクセスされる絶 対度数はともかく，アクセスした時の満足度とい う観点からは, 個人蓄積情報, 社内作成資料, 社 内人脈に対する評価が高い。

しかし, 満足度に対するこのような傾向は, 3.4 で考察した各アクセス手段に対する満足率（表 9 を見よ）の傾向とはほとんど相関がない。これは 一見奇妙に見えるが，この二つの満足性指標の意 味が違うことを理解すべきである。すなわち，表 9 に示される満足率は, 各々のアクセス手段が利 用された中で，それが他のアクセス手段に比して， よりましな手段となったという相対的満足性の高 さである（各情報アクセス行動に対して 3 通り以 内のアクセス手段をとり，その中で最も満足した 手段を問うたことを想起されたい)。一方図７に示 す満足度の得点は，上記の比較的ましだった満足 手段に対して，それによって入手した情報の絶対 的満足度を答えたものと考えられる。 


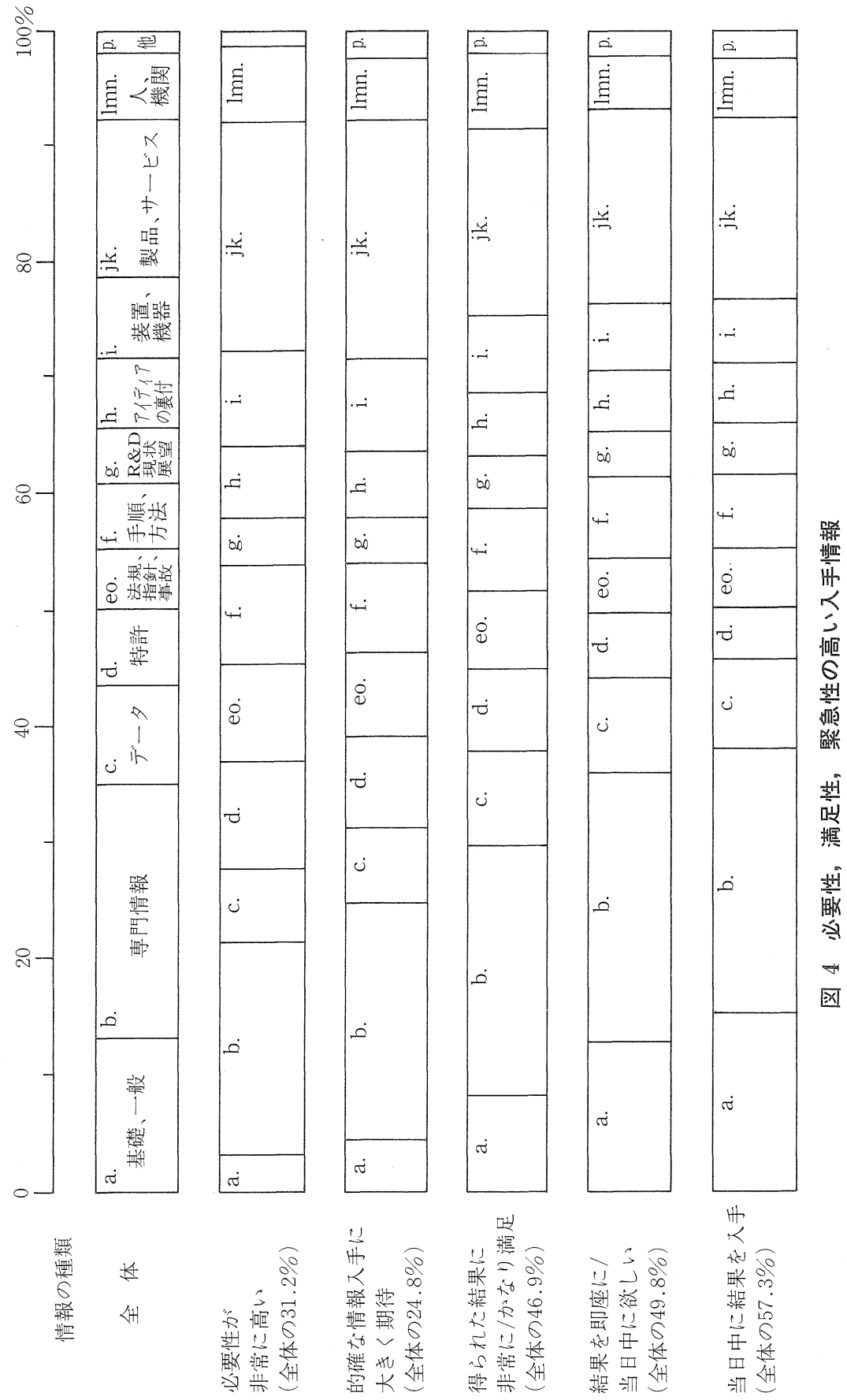



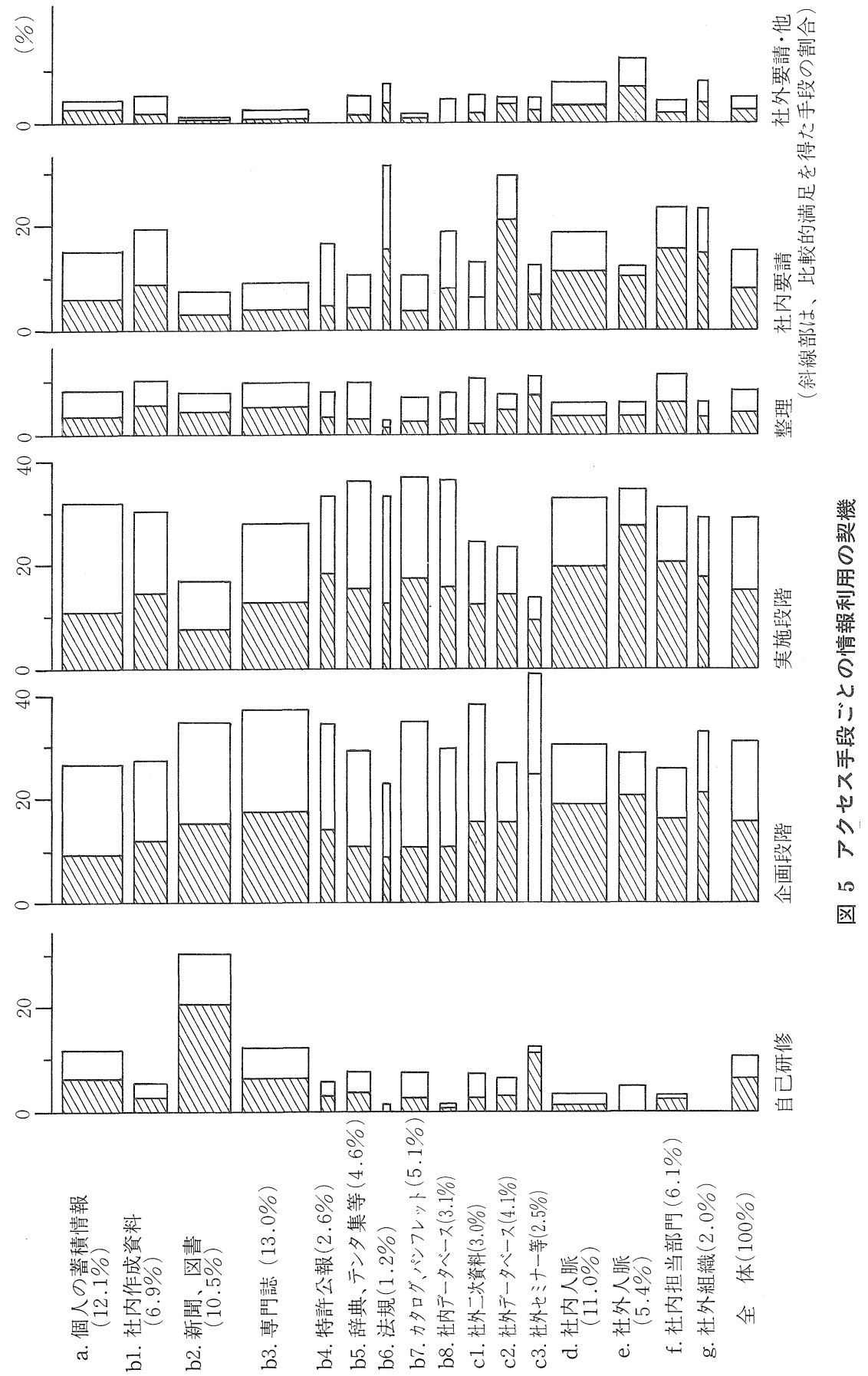

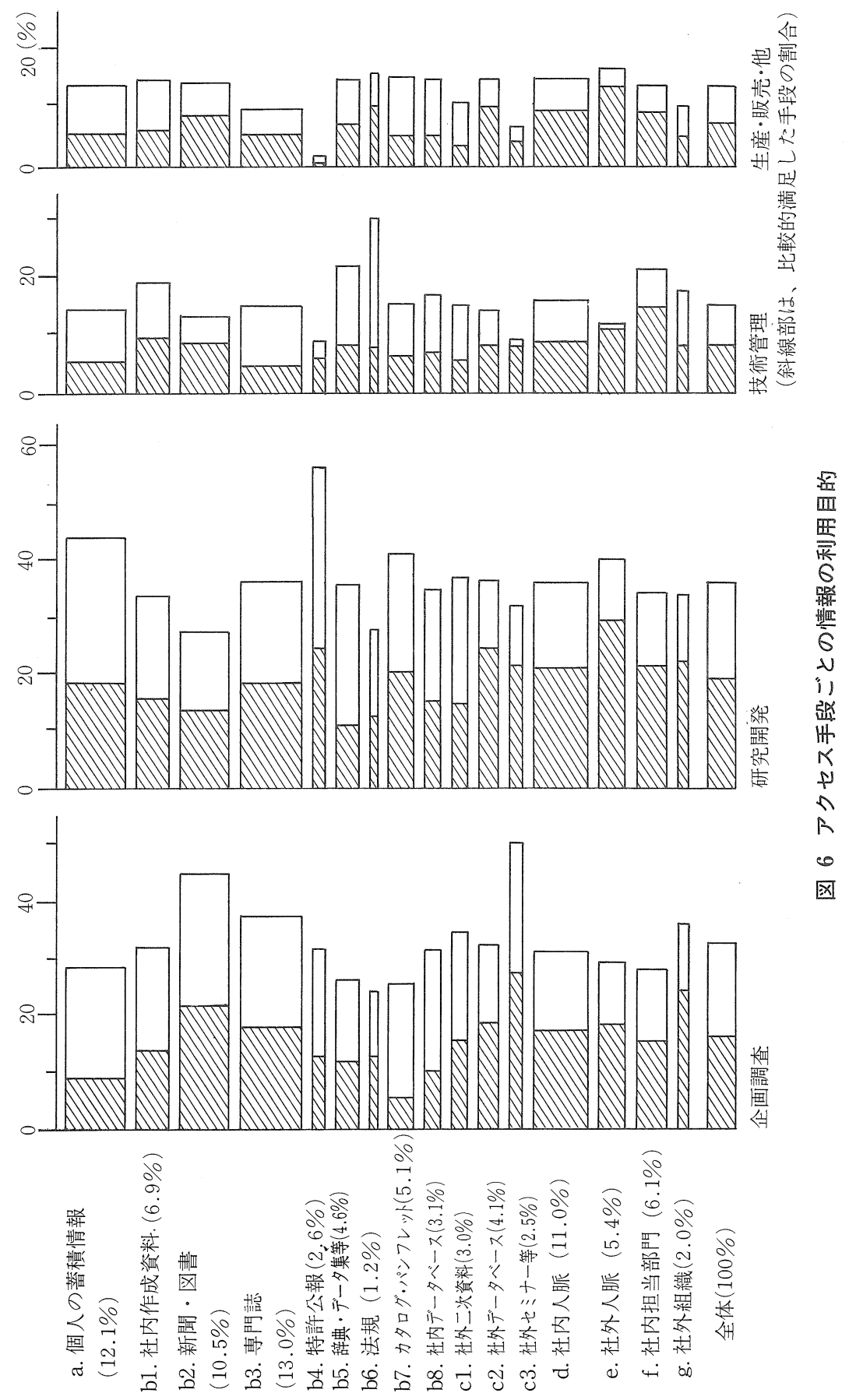


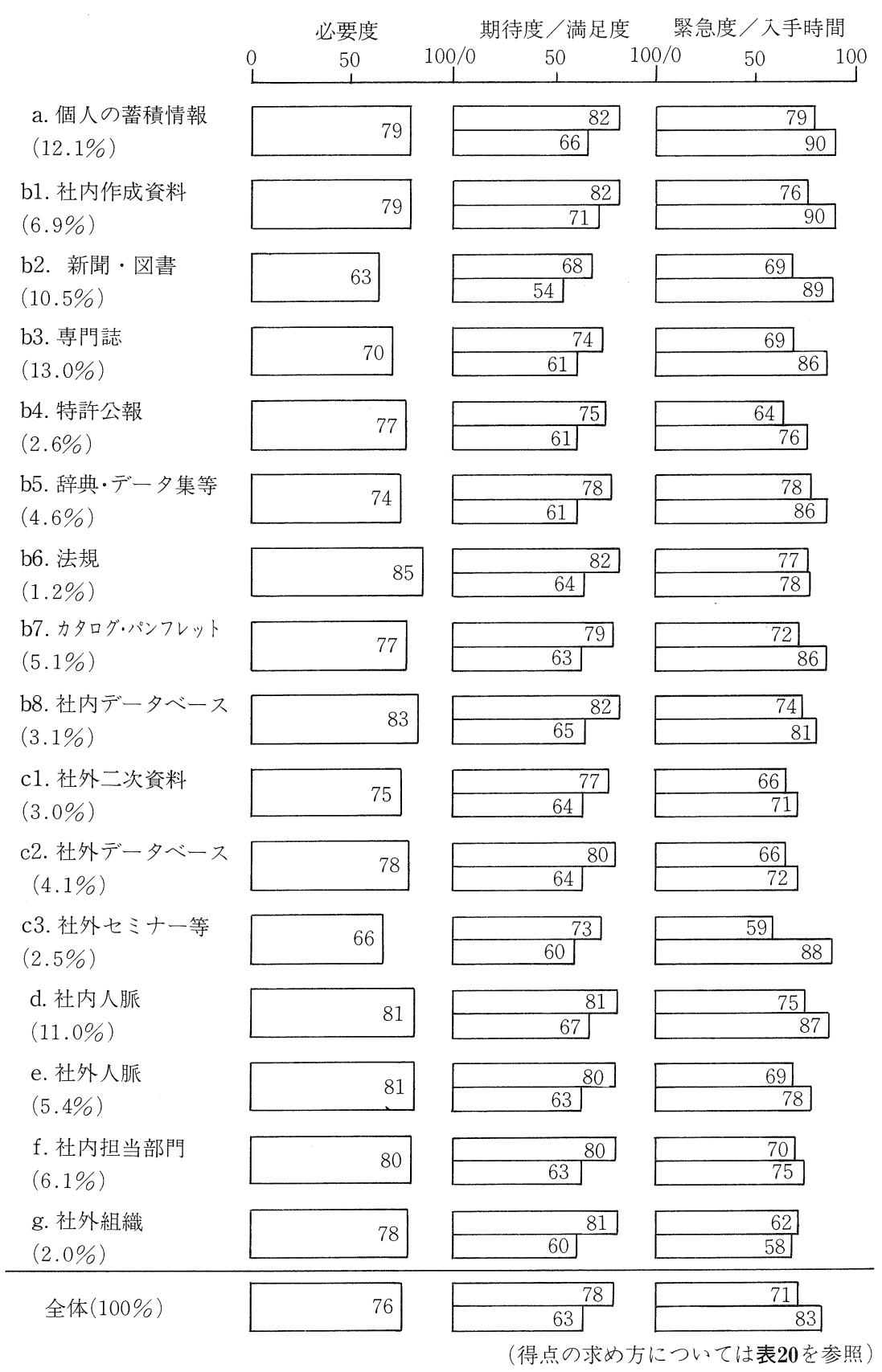

图 7 アクセス手段ごとの必要度, 期待度/満足度, 緊急度/入手時間得点 
緊急度と入手時間に関しては，個人蓄積情報， 社内作成資料，辞典・デー夕集のような手近かな 手段の評点が高く, 社外二次資料, 社外データべ 一ス，社内担当部門，社外組織の評点が低いこと
は止むを得ないであろう。

図 8 には，必要性と緊急性が特に高いとされた 回答についてのみのアクセス手段の利用比を, 全 体の利用比と比較している。斜線部は, 満足を得

a. 個人の蓄積情報

b0. 社内蓄積情報 b1. 社内作成資料

b2. 新聞・図書

b3. 専門誌

b. 特許公報

b5. 辞典・デー夕集等

b6. 法令・規格

b7.カタログ、ペフレット

b8. 社内データベース b9. 社内セミナーー b10. その他 $\mathrm{c} 0$. 社外蓄積情報 c1. 二次資料 c2. 社外データベース c3. 社外七ミ十一等 c4. その他 d. 社内人脈

e. 社外人脈

f. 社内担当部門

g. 社外組織利用 h. その他

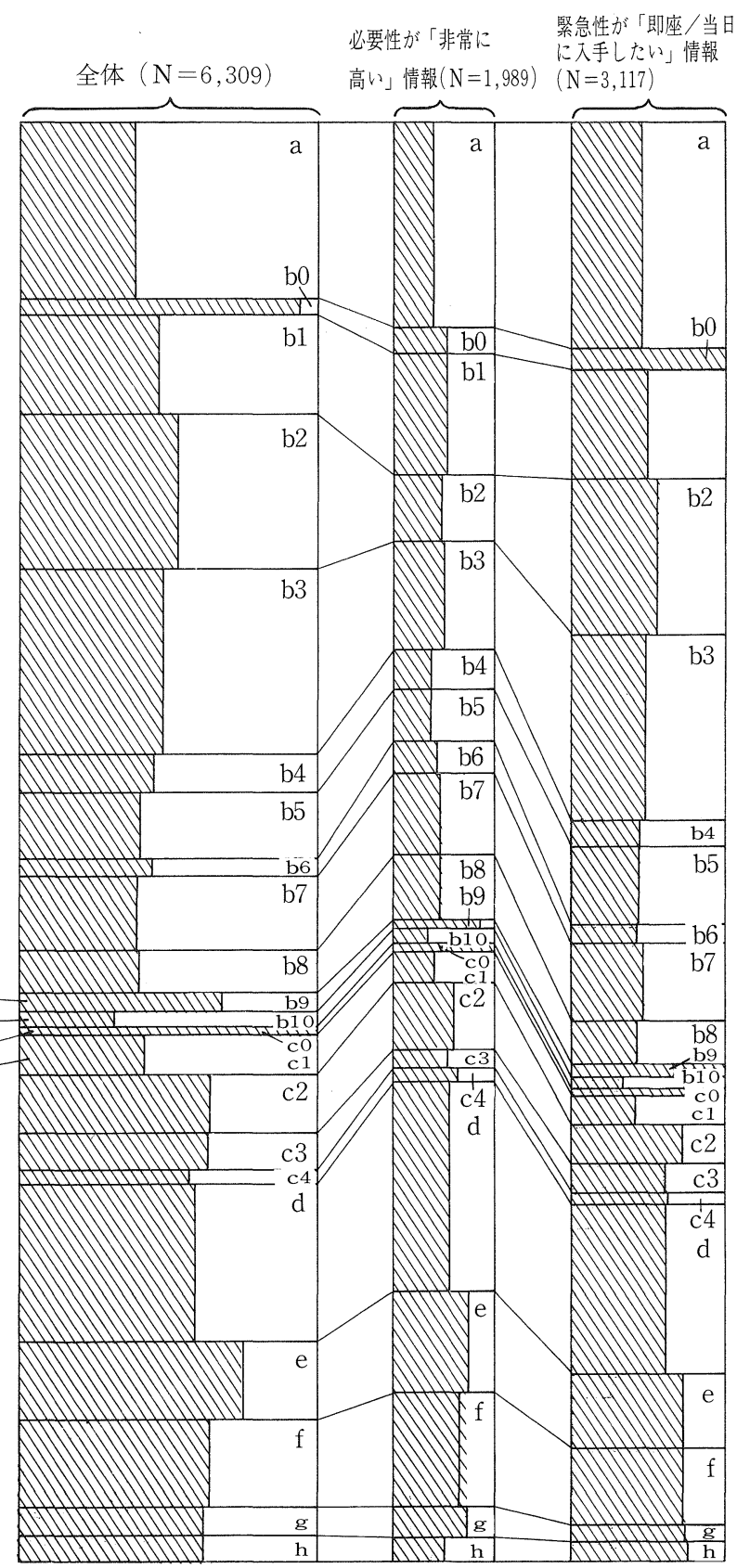

図 8 必要性, 緊急性の高い情報に対するアクセス手段 


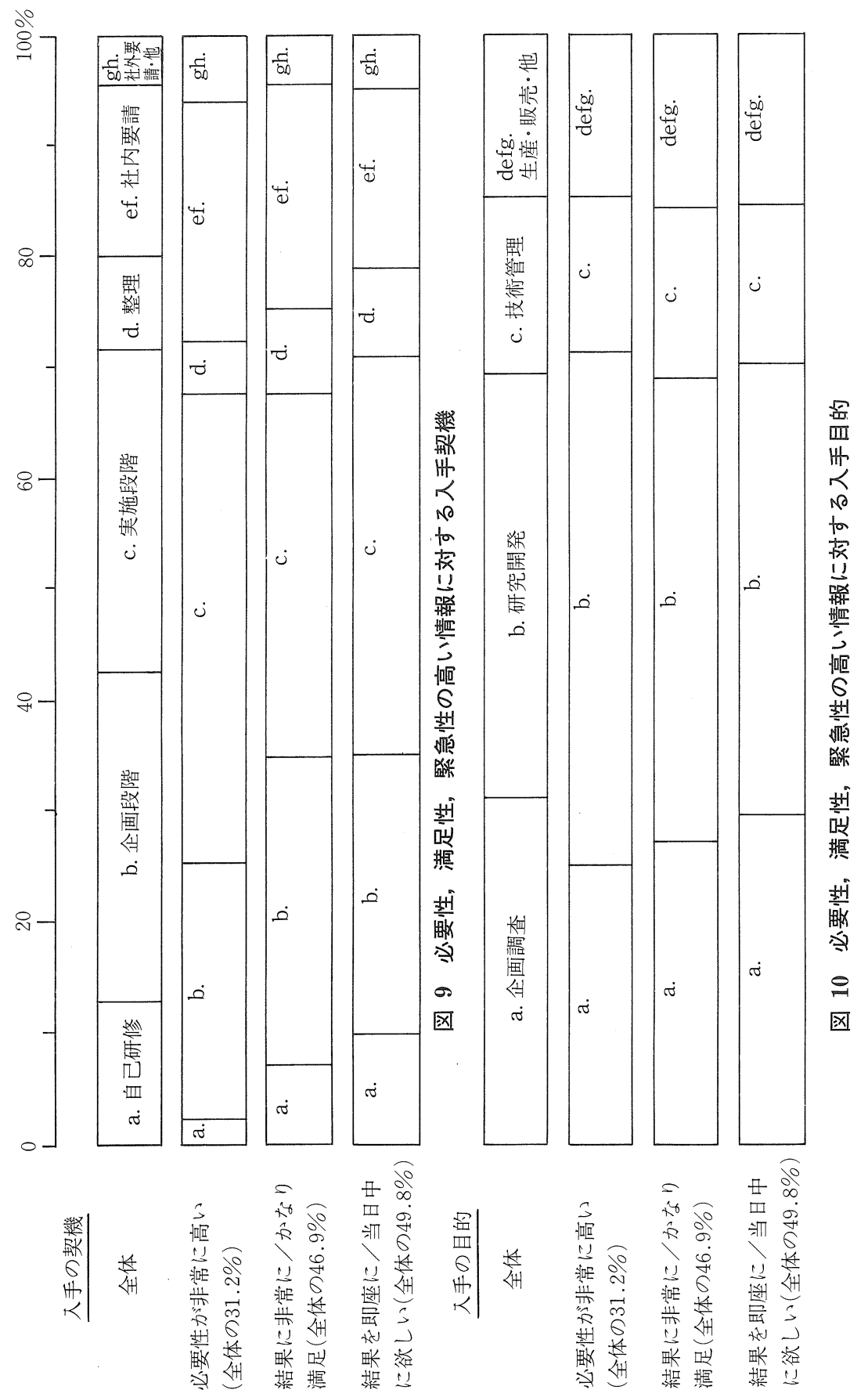


たアクセス手段の割合を表している。

\section{3 その他の項目間の関係}

（1）必要性，満足度，緊急性の高い情報の入手契 機と入手目的

情報入手の必要性と緊急性，および得られた情 報に対する満足度の高い回答のみについて，入手 の契機と目的を集計した結果を図 9, 図 10 に示し
た。研究開発の実施段階での情報要求は，必要性， 緊急性が最も高いことがわかる。また，社内の上 司・同僚，他部門からの要請による情報入手に， 必要性が高いとする回答が相対的に多いが，これ は，企業においてはこのような形での情報流通が 重要であることを示しているものと考えられる。

(以下，次号へ続く)

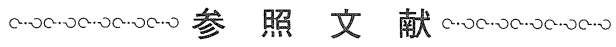

1）科学技術情報の流通促進のための進展する情報 技術の活用方向に関导る調查研究報告書。東京。(財) 未来工学研究所。 1986， 232 p.

2) W. D. Garvey, N. Lin, C. E. Nelson, K. Tomita. Research Studies in Patterns of Science Communication. Information Storage and Retrieval. Vol. 8 (1972)
以下に日本語での詳しい紹介と解説あり。 学術研究情報の流通に関する調查報告第 1 回 ～第 7 回。ドクメンテーション研究.Vol.23，No. 5 (1973) Vol.24, No. 1 (1974)

3）丸毛一彰他。企業に招ける研究者・技術者の情報 大手活動。第 26 回情報科学技術研究集会発表論文 集。175-184（1990） 